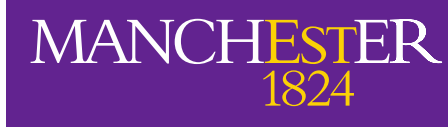

The University of Manchester

\title{
Economics
}

Discussion Paper

Series

EDP-2004

\section{The efficiency of the Chinese silver standard, 1920-33}

Nuno Palma and Liuyan Zhao

\author{
May 2020 \\ Updated July 2021
}

Economics

School of Social Sciences

The University of Manchester

Manchester M13 9PL 


\title{
The efficiency of the Chinese silver standard, 1920-33
}

\author{
Nuno Palma \\ (Dept. of Economics, Univ. of Manchester; ICS, Univ. de Lisboa; CEPR) \\ Liuyan Zhao \\ (School of Economics, Peking University)
}

\begin{abstract}
We test for integration of financial markets in China during 1920-1933 using a new dataset of domestic exchange rates. Our data concerns tael-denominated telegraphic transfers between Shanghai and nine other cities. We find that Chinese financial markets, as measured by the efficiency of silver-point arbitrage, were highly integrated among major commercial hubs in north and central China, but there was a lower level of integration for more remote cities in the south. Our paper presents the first comprehensive assessment of the efficiency of the Chinese silver standard, and contributes to a revaluation of market performance during pre-communist China.
\end{abstract}

Keywords: silver point arbitrage, market integration, exchange rates, Chinese economy

JEL Codes: N15, N25

ForThCOMing IN: Journal of Economic History

\footnotetext{
${ }^{\star}$ Corresponding author: L. Zhao (zhly@pku.edu.cn). We thank the editor Eric Hilt, two anonymous referees, Markus Eberhardt, Debin Ma, and Meng Wu for comments. Joakim Book, Javier Charotti, Nicholas Gachet and Nick Ridpath provided research assistance. Financial support to Nuno Palma from Fundação para a Ciência e a Tecnologia (CEECIND/04197/2017) and to Liuyan Zhao from the National Social Science Foundation of China (20BJL120) are gratefully acknowledged.
} 


\section{INTRODUCTION}

In the early twentieth century, China remained on a silver standard while most of the world aspired to join the gold standard (Meissner, 2005; Mitchener et al., 2010; Fernholz et al., 2017). But while the experiences of Western countries have received much attention in the literature, there has been much less research on the operation and efficiency of the silver standard in China, despite its size and comparative importance 11 In this paper, we consider China's degree of financial integration by studying the efficiency of domestic exchange markets during 19201933. We consider ten Chinese cities, all of which were on a silver standard. According to most of the literature, market fragmentation prevailed during this period: domestic markets were segmented due to a largely self-sufficient peasant economy, backward transportation, and low state capacity. The latter led to political instability and various warlords controlling different regions of the country ${ }_{2}^{2}$ Using a new dataset of domestic exchange rates we find that financial markets in cities of north-central China were highly integrated both during most of the Warlord Era (1916-28) and in the Nanjing Decade (1928-37). There was, however, a lower degree of integration for remote cities located in the south of the country.

China in the early twentieth century was characterized by political chaos but also fundamental economic and financial transformations. The collapse of the Qing Imperial Government in 1911 ushered in what turned out to be a chaotic Warlord Era, when China was divided among several military cliques, with various warlord factions vying for power. The self-styled national government in Beijing lacked both revenue and effective authority, although it enjoyed legitimacy and diplomatic recognition abroad. Civil strife became the norm, with no ruler having effective control over the whole country (Ma, 2016) ${ }^{3}$ After the military campaign known as the Northern Expedition, the Nanjing Decade (1928-37) under the new Nationalist government led by Chiang Kai-shek was more cohesive than the preceding Warlord Era, though it was cut short by Japan's invasion in 1937. Nevertheless, it was in this era that China experienced the first full-swing surge of industrialization and modernization. Political fragmentation and prolonged weakness at the center offered opportunities for experimentation with new ideas and institutions, giving rise to what we now know as a golden age of the Chinese bourgeoisie (Brandt et al., 2014).

The degree of market development and economic performance under the silver standard in pre-communist China has long been a source of debate. China was an agrarian state in an early stage of economic development, but its eastern seaboard was considerably more developed than its interior. A long-held view maintains that markets were underdeveloped and regional economies were fragmented (Skinner, 1977; Rawski, 1972). This fragmentation has been blamed on inadequate transport systems against a background of weakening fiscal capacity of the state

\footnotetext{
${ }^{1}$ There is a large literature on the operation of the gold standard in the nineteenth and early twentieth centuries. Key contributions include Morgenstern (1959), Clark (1984), Marcuzzo and Rosselli (1987), Canjels et al. (2004), Flandreau (2004), Coleman (2007), Officer (1996), Esteves et al. (2009), and Nogues-Marco (2013).

[Skinner (1977) argues that China was in fact for centuries composed of eight physiographic regions, each largely self-sufficient.

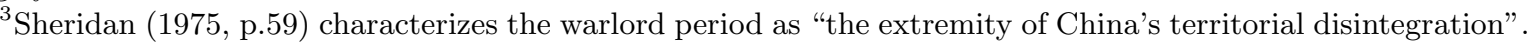
About 140 conflicts involving more than 1,300 rival military groups took place between 1911 and 1928 (Billingsley, 1988, p.24).
} 
(Bernhofen et al., 2015; Elvin, 2004, Perkins, 1969; Sng, 2014). The existing debate mainly concerns the development of integration in commodity markets, and there is a relative paucity of research into the monetary and financial aspects of China's economic transformation 4 In fact, China's experience with its silver standard in the early twentieth century has been largely neglected. According to the limited literature that exists, financial market fragmentation prevailed during this period. Brandt et al. (2014) argue that Chinese financial markets were segmented as interest rates differed substantially across regions - annual interest costs on unsecured personal loans during the 1930s ranged from 20-30 percent in coastal provinces to 50 percent in less commercialized provinces. Moreover, wide variations also existed in interior provinces: for instance, the average annual interest rate paid by farmers varied from 22 percent in Jiangxi to 40 percent in Henan (Chiao and Yin, 1937). Commenting on the financial crisis in Shanghai in 1934, an official report stated that "Since the silver crisis developed last year Shanghai has suffered more seriously than any other city in China. The other ports, being financially dependent on Shanghai, have naturally also suffered, though not so seriously as Shanghai. The interior of China has been affected scarcely at all and is quite unable to understand the crisis that has arisen in Shanghai" (North-China Herald, 1935). The few scholars who have examined the development of financial markets in China have done so using case studies or descriptive statistics to summarize market development (Ma, 2008b; Yan, 2012). As a consequence, we do not have a good scholarly understanding of the China's silver regime and of the process and degree of integration of Chinese financial markets.

In the present paper, we lay out the conditions of the monetary system in China and examine how well its silver standard functioned. The traditional silver currencies used in China were not produced by a central authority. Instead, the circulation of a particular kind of silver currency was confined to each local trading area (Kann, 1927, p.60). This characteristic of China's silver regime generated a domestic exchange market that was conceptually analogous to the foreign exchange markets between the gold standard countries, meaning we can rely on the large literature on gold point arbitrage as a framework.

We formalize the mechanism of silver arbitrage in the presence of transaction costs as it relates to the special circumstances within China, and use our model to test the degree of market integration. The lack of available high-frequency data has been a considerable barrier to studying Chinese financial markets in this period. To overcome this, we collected a comprehensive dataset on daily and weekly market domestic exchange rates and the volume of the flow of silver currency between Shanghai and financial sub-centers of China 5 To the best of our knowledge, we are the first to provide a comprehensive empirical assessment of the efficiency of Chinese domestic exchange markets under the silver regime. Using this high-quality dataset, we apply threshold autoregressive (TAR) models to estimate silver points - the transaction costs associated with silver arbitrage. To cross-check the reliability of our results, we consider the relationship between our indirect measures of silver points and direct measures of physical flows of silver currency

\footnotetext{
${ }^{4}$ Port cities and the countryside are often argued to have had independent markets; see for example, (Ho and Lai, 2013 Brandt et al., 2014, Du, 2018).

As Canjels et al. (2004 p.869) note, high-frequency data are ideal for this purpose as they closely correspond to the adjustment horizon in exchange markets.
} 
derived from contemporaneous accounts.

For Shanghai and major commercial hubs in north and central China, we find that financial markets behaved efficiently despite the fragmentation of silver standards. Based on our estimates of silver points, and assuming disutility is incurred from violations of the no-arbitrage principle, we also compare the efficiency of Chinese domestic exchange markets with that of the transAtlantic and intra-European exchange markets. Our results show that, with the exception of the period of the Northern Expedition, the exchange-market efficiency of the silver standard in north-central China was not much different in magnitude to that of the classical DollarSterling gold standard before World War I. We hence conclude that there was a substantial degree of integration in Chinese financial markets before World War II. We attribute this fact to technological advancements such as the rapidly expanding railway and telegraph lines, to monetary innovations, and to China's low labor costs which contributed to low transportation costs. Nevertheless, we also find that market performance in remote regions and smaller cities was lower than that among major trading centers, as would be expected given the distance and political instability context.

While in recent years a literature on Chinese market integration has emerged, most market efficiency benchmark comparisons between Western Europe and China have focused on agricultural commodities (Brandt, 1989; Wang, 1992; Li, 2000; Shiue, 2002, Shiue and Keller, 2007). By contrast, we provide an assessment of the efficiency of domestic exchange markets within precommunist China. Ma and Zhao (2020) study Chinese monetary integration in North China and the Yangtze River Valley during the early twentieth century based on the prices of silver dollars in different cities. By the 1920s silver dollar-convertible banknotes (issued by large Shanghai banks) had largely replaced silver coins in circulation ${ }^{6}$ As banknotes were easier to ship, Ma and Zhao (2020) may be underestimating the silver points and thus overestimating the degree of integration in those regions. In this paper, we measure monetary integration based on the domestic exchange rate and the flows of hard currency (sycee). This reveals true silver points: the costs of silver movements between commercial centers. We additionally consider a much wider region of China including remote areas in the south of the country.

Our study carries implications for the historical understanding of market integration at a time of political disintegration and contributes to a revaluation of economic development during China's Republican period. Our finding that the Chinese silver standard was remarkably efficient in parts of China despite political turmoil and weak central state capacity is consistent with the existing evidence of economic growth taking place during this period in the area around Shanghai (Ma, 2008b). Elsewhere, economic development in the period up to World War II was kept in check; our finding that remote areas of China faced high transaction costs matters for understanding this uneven regional development.7

\footnotetext{
${ }^{6}$ See Kuroda (2005, p.116), Morota (2013, p.388), and Feng (1926).

${ }^{7}$ Our analysis of Chinese domestic markets complements previous work which considers Chinese foreign exchange market efficiency during the same period, and similarly finds that it was more efficient than previously believed (Jacks et al., 2017).
} 


\section{Arbitrage in the Chinese Silver EXCHANGE}

\subsection{Historical background: China's domestic exchange market}

The late nineteenth century was a time when most countries aspired to join the gold club. An important exception was China, which remained the large silver outlier. This choice has been bemoaned as a symptom of China's political and economic woes (Friedman, 1992). The Chinese government did not effectively define or control the weights, fineness and shape of the silver currency used within the country, despite occasional standardization attempts. These tasks were left to local governing bodies, such as chambers of commerce and corporations. Therefore, the silver basis of Chinese traditional currency was not in standard coinage, but in the form of ingots called sycee, with each piece generally weighing around 50 ounces. The production of sycee was controlled by local silversmiths' guilds. Therefore, the pure silver contained in sycee was not nationally uniform, different local institutions manufactured sycee without standardized methods. Naturally, the circulation of any kind of sycee was usually confined to the locality for which they were originally created, and when taken to different localities they had to be melted or re-assayed (Kann, 1927, p.90).

Spanish-American silver coins were first introduced to China during the Ming dynasty. Over the course of several centuries, many kinds of foreign dollars made their appearance in China, though Spanish-American dollars retained central importance. It was not until the end of the nineteenth century that dragon dollars - the Chinese silver coins produced by various provincial mints - made their appearance on the market. As with the sycee, they were not subjected to government control. This explains their lack of uniformity, and the subsequent confusion that they caused. The dragon dollars were often accepted by the public by weight, instead of by count $(\mathrm{Kann}, 1927, \mathrm{p} .151) \mathrm{A}^{8}$

In the following decades, the silver dollar and sycee performed different functions. The sycee was often used for account clearings within financial institutions, while silver dollars were more likely to be used in actual circulation (Kann, 1927, p.336). To satisfy the need for a common unit of account within the mixtures of currencies, the tael, a 'Chinese ounce' of silver, emerged for various commercial zones prior to the end of the Qing regime. The tael provided a reliable anchor against which the value of the amalgam of currencies could be measured. Nevertheless, every commercial center had its own tael. Among the various local taels used, the best known and the most widely used were the Shanghai Tael (hereafter ST), followed by the Tianjin Tael (TT), the Hankou Tael (HT), and the Beijing Tael (BT).

This mixed system of silver currencies generated domestic exchange markets among various silver currencies for major trading zones (known as neihui in Chinese). Particularly important was the exchange of the Shanghai Tael against other local taels. This was analogous to the foreign exchanges of the gold standard countries. Usually, the balance of inter-port trade within China was adjusted by means of bills of exchange or telegraphic transfers. However, if the balance of

\footnotetext{
${ }^{8}$ It was only in 1914, after the founding of the new Republic, that a national dollar was introduced. The uniformity and reliability of the national dollar made it an unparalleled success, gradually replacing both foreign currencies and a heterogeneous collection of dragon dollars (Ma and Zhao, 2020).
} 
trade between two commercial ports within China favored one of them for a prolonged period, the balance had to be settled by means of shipments of silver specie (typically, sycee).

\subsection{Silver arbitrage}

During our period, domestic trade in China was financed mainly by the Chinese native banks ${ }^{9}$ The native banks in Shanghai began to be active from the middle of the nineteenth century and were to become the center of gravity of China's financial system. By 1875, more than one hundred such institutions operated in Shanghai. Primarily with their own capital, the Shanghai native banks set up a network of branches or agents throughout the whole country ( $\mathrm{Wu}, 1935 \mathrm{~b})$.

There were two primary exchange instruments that traders could use for their operations: bills of exchange and cable transfers (Yang, 1936, p.413). The traditional exchange instrument was the bill of exchange, issued by Shanghai native banks and popularly known as the "Shanghai bill." Denominated in Shanghai taels and drawn on a party in Shanghai, it was traded in the exchange markets of almost all major cities. But it could be redeemed at its Shanghai tael face value only when, having been shipped to Shanghai, it was presented to the Shanghai drawee. Shanghai bills fell into two categories: sight bills and time bills. The distinction concerned whether they were payable from 0 (sight/demand bill) to 30 days after sight ${ }^{10}$ Shanghai native banks maintained an unblemished record in redeeming their bills for a long time, thus successfully gaining the public's confidence. Most domestic trade throughout China was conducted with these credit instruments. This brought about an advanced exchange market for Shanghai bills in major commercial centers $(\overline{\mathrm{Wu}}, 1935 \mathrm{~b})$. As a contemporaneous observer wrote, the "Shanghai bill functioned, in a sense, as a national currency used popularly in domestic trade between the major commercial ports" (People's Bank of China, 1989, p.185).

The second exchange instrument, the cable order, was faster and a common instrument of transfer for banks. The spot cable rate was analogous to the exchange rate for sight Shanghai bills. In the case of cable orders, the purchasers of TT made ST payments and received their TT simultaneously. In contrast, with Shanghai bills there was a delay for shipment and presentation, even for sight bills (and for time bills an additional wait was necessary).

As an example, let us consider how silver and sight Shanghai bills circulated between Shanghai and Tianjin. We consider first silver-export arbitrage, from Shanghai, via the Shanghai bill 11 This is the case where silver is overpriced in Tianjin relative to sight bills, that is, the

\footnotetext{
${ }^{9}$ Chinese native banks performed a function that was indispensable to domestic commerce. The banks of Shanxi, established at least as early as the beginning of the eighteenth century, introduced one of the first known systems of draft remittances between distant locations. By contrast, foreign trade was financed primarily by foreign banks. Their dealings with Chinese merchants had to be handled through native banking institutions via their comprador offices. The reason was that foreign banks, although occupying a strong position in major cities on account of their larger resources, were unable to maintain organizations covering the vast territory of the interior cities (Nishimura, 2005).

${ }^{10}$ For instance, when a Shanghai purchaser went to Tianjin, instead of taking silver cash with him, he could simply borrow from the native banks in Shanghai. He merely asked his bank for the desired sum in bills of exchange. Then he took the Shanghai bill to a native bank in Tianjin, and sold (or discounted) it for cash or for a Tianjin native bank order (analogous to checks issued by modern banks) with which he could purchase cotton in that city. The Tianjin native bank in turn sold the Shanghai bill to a Tianjin merchant who wanted to go to Shanghai to purchase goods there.

${ }^{11}$ Throughout the discussion, the exchange rate expresses the price of one unit of 'other local tael' (Tianjin Tael
} 
sight exchange rate is higher than the mint parity (plus the costs of shipping silver from Shanghai to Tianjin). Table 1 relates flows in the quantity of silver and sight bills in an arbitrage transaction. The arbitrageur begins his operation at time $t=0$ by buying sight Shanghai bills in Tianjin at the market rate $\left(e_{0}\right)$, and ships the bills to Shanghai. The time for a one-way voyage is here standardized as 1 . At $t=1$ he presents the bills to the drawees, uses the ST proceeds to obtain silver from banks in Shanghai at the mint parity, $C^{S H}$ (that is, the fixed silver content in the ST), and transports the silver to Tianjin for conversion to TT at the mint parity $C^{T J}$ at $t=2$. In this case, ST are bought at the market exchange rate and sold at mint parity via the silver transaction. The revenue is the deviation of the market rate $e_{0}$ from the parity rate $e^{p a r}$ (that is, the ratio of fixed silver contents in TT and ST). As for costs, in addition to shipping, interest is lost for the duration of a round-trip voyage, since silver is shipped from Shanghai only after the bills have arrived from Tianjin.

We now turn to the converse operation: silver imports (into Shanghai) arbitrage via Shanghai bills (Table 2). The arbitrageur begins his operation by selling Shanghai bills at the market rate in Tianjin, thereby obtaining TT with which to purchase silver from the Tianjin banks. The silver is transported to Shanghai and sold to banks, with the ST proceeds used to cover the Shanghai bills upon presentation. In this case, ST are effectively purchased at the mint parity $\left(e^{\text {par }}\right)$ via the intermediary of silver, and sold at the market rate that prevailed at time $0, e_{0}$. Therefore, the arbitrageur's revenue is the absolute value of the deviation of that market rate from parity.

Table 1: Silver flow from Shanghai to Tianjin, with $e_{0}>e^{p a r}$

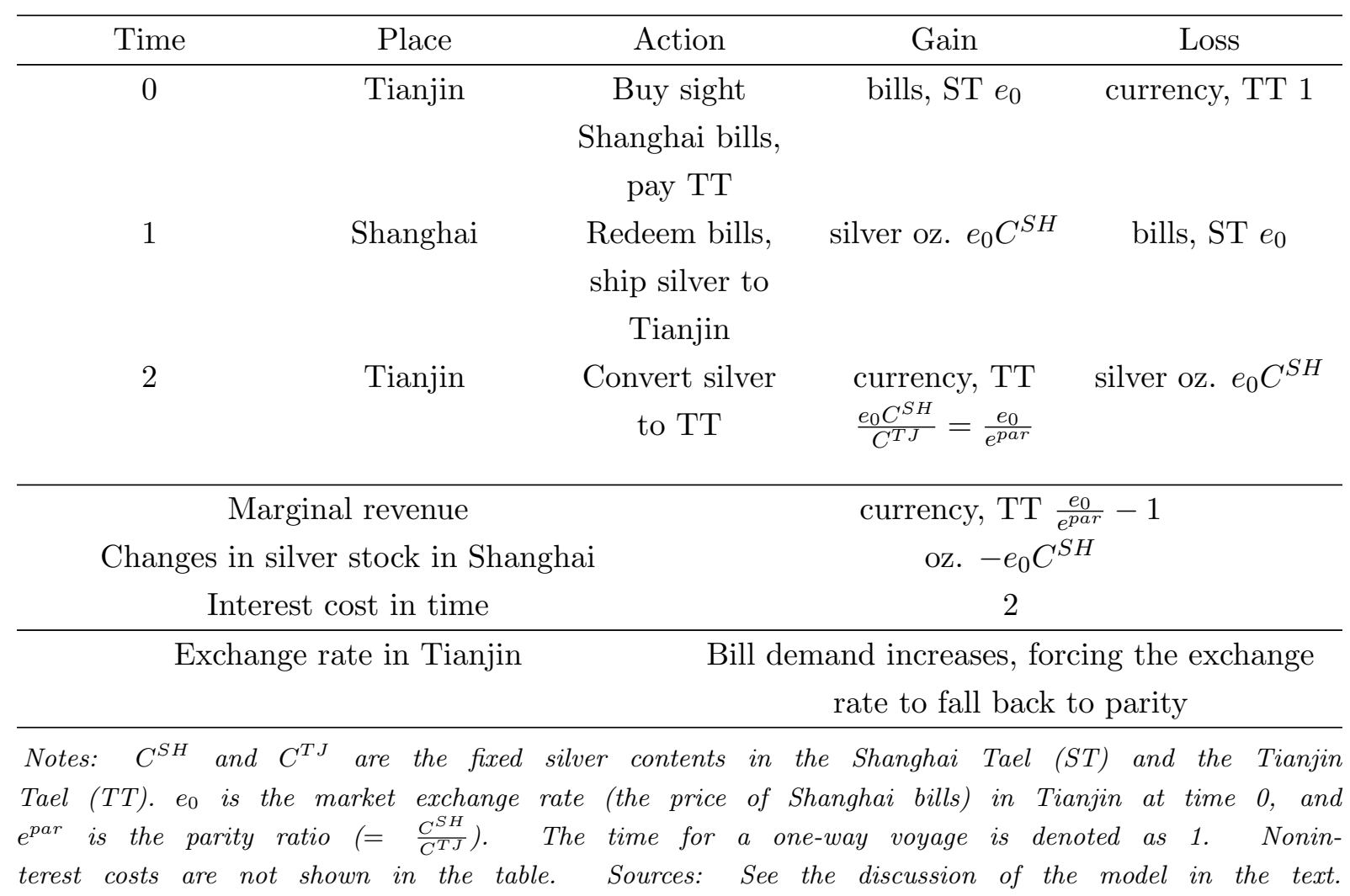

for instance) in terms of Shanghai Tael. Thus, an appreciation of the exchange rate means that the Tianjin Tael is strengthening and Shanghai Tael is depreciating. 
Table 2: Silver flow from Tianjin to Shanghai, with $e_{0}<e^{\text {par }}$

\begin{tabular}{|c|c|c|c|c|}
\hline Time & Place & Action & Gain & Loss \\
\hline 0 & Tianjin & Sell sight & currency, TT $\frac{1}{e_{0}}$ & bills, ST 1 \\
\hline 0 & Tianjin & $\begin{array}{c}\text { Shanghai bills } \\
\text { Buy silver, ship } \\
\text { silver to } \\
\text { Shanghai }\end{array}$ & silver oz. $\frac{C^{T J}}{e_{0}}$ & currency, TT $\frac{1}{e_{0}}$ \\
\hline 1 & Shanghai & $\begin{array}{c}\text { Convert silver } \\
\text { to } \mathrm{ST}\end{array}$ & $\begin{array}{l}\text { currency, } \mathrm{ST} \\
\frac{C^{T J}}{e_{0} C^{S H}}=\frac{e^{\text {par }}}{e_{0}}\end{array}$ & silver oz. $\frac{C^{T J}}{e_{0}}$ \\
\hline 1 & Shanghai & $\begin{array}{l}\text { Draw up sight } \\
\text { bills, ship bills } \\
\text { to Tianjin }\end{array}$ & bill, ST $\frac{e^{\text {par }}}{e_{0}}$ & bill, ST $\frac{e^{p a r}}{e_{0}}$ \\
\hline 2 & Tianjin & Arrival of bill & & \\
\hline \multicolumn{3}{|c|}{ Marginal revenue } & \multicolumn{2}{|c|}{ bill, $\mathrm{ST} \frac{e^{p a r}}{e_{0}}-1$} \\
\hline \multicolumn{3}{|c|}{ Changes in silver stock in Shanghai } & \multicolumn{2}{|c|}{ oz. $+\frac{C^{T J}}{e_{0}}$} \\
\hline \multicolumn{3}{|c|}{ Interest cost in time } & \multicolumn{2}{|l|}{2} \\
\hline \multicolumn{3}{|c|}{ Exchange rate in Tianjin } & \multicolumn{2}{|c|}{ ate to increase back to parity } \\
\hline & Sources: & See & table & \\
\hline
\end{tabular}

The situation was analogous when a telegraphic transfer was employed as the exchange instrument 12 Although Shanghai bills were the traditional exchange medium for domestic trade within China, telegraphic transfer was the dominant medium for domestic exchange in our study period; as the economist Wu Daye wrote then, "Sight exchange rate is less important than spot cable rate in China" (Wu, 1935a) 13 Contemporaneous official publications cite either the spot cable rates only, or both the spot cable rate and the sight exchange rate for Shanghai bills 14 We have rarely seen any newspapers citing only sight exchange rates.

\section{DATA AND THE ESTIMATION OF SILVER POINTS}

We use domestic exchange rate data to establish thresholds on silver arbitrage. We begin by describing the data and econometric model that we use. We then estimate the silver points between Shanghai and other major and secondary cities using exchange rates data, and we

\footnotetext{
${ }^{12}$ The difference was the opportunity cost of investing in a risk-free asset, since the time of shipping bills was saved.

${ }^{13} \mathrm{~A}$ contemporaneous investigation report also wrote that (our translation): "When nonlocal merchants come into Shanghai to purchase cotton textiles, their dominant exchange instrument is the telegraphic transfer. For instance, [when] Tianjin merchants go to Shanghai, they generally remit cash by telegraphic order, which is the primary financial source for them" (People's Bank of China (Shanghai Branch), 1960, p.184).

${ }^{14}$ For examples of the former, see Economic Statistics,, Banker Weekly, and Peking Bankers' Magazine, while for the latter, see the Hankou Bankers' Magazine
} 
corroborate these results against contemporaneous reports of the cost of silver shipment between cities. We find that there was a high degree of financial markets integration for the main cities.

\subsection{Data}

We collected domestic exchange rates based on Shanghai tael-denominated telegraphic transfers drawn on Shanghai and settled in other cities. We first examine the exchange rates between Shanghai and three major regional financial centers for the 1920s and 1930s. These cities Tianjin, Hankou and Beijing - had prime commercial importance in China 15 Therefore, their daily rate (paired with Shanghai, the national financial center) was tabulated uninterruptedly in contemporaneous publications ${ }^{16}$ We then move to the analysis of the more partial evidence available for six other smaller or more remote cities ${ }^{17}$ Figure 1 shows all our sample cities in a map of China which emphasizes how they were connected to each other via water or railways.

\footnotetext{
${ }^{15}$ Shanghai was the financial, commercial, and industrial center of China. Tianjin was the commercial center of North China and the second biggest financial center of China, next only to Shanghai. Hankou later merged with two other historical cities, Wuchang and Hanyang, becoming today's Wuhan. It ranked as the most important financial center in the heartland of China, with Shanghai and Tianjin serving coastal China. Beijing had been the political capital before 1928 but ceased to be as important a regional financial market as Tianjin or Hankou once the capital was changed to Nanjing (Ma 2008b). Ma (2008b) analyzes the operation of China's nationwide hierarchical financial network with Shanghai as the center and Tianjin, Hankou and Beijing as the most important satellites of the Shanghai money market. See also (Chinese Weekly Economic Bulletin, 1924, pp.1-9) and (Bureau of International Trade, Ministry of Industry, 1932, p.243).

${ }^{10}$ In the Appendix, we show two examples of what these publications looked like.

${ }^{17}$ Of these, two are in the Shandong province of North China: Jinan (data available for Aug. 1921-Dec. 1924) and Qingdao (Aug. 1921-Dec. 1925); three are in the Sichuan province of Southwest China: Chongqing (Aug. 1921-Dec. 1929), Wanxian (Aug. 1921-Dec. 1929) and Chengdu (Aug. 1921-April 1926); and one city is located in Southeast China: Guangzhou (Aug. 1925-Dec. 1931). Guangzhou was the biggest city in South China but was remote relative to the central areas of China. Moreover, it was dominated by local warlords, not the central government, and used a rather different currency than that used in Shanghai (although both were based in silver).
} 
Figure 1: Distribution of cities in our sample

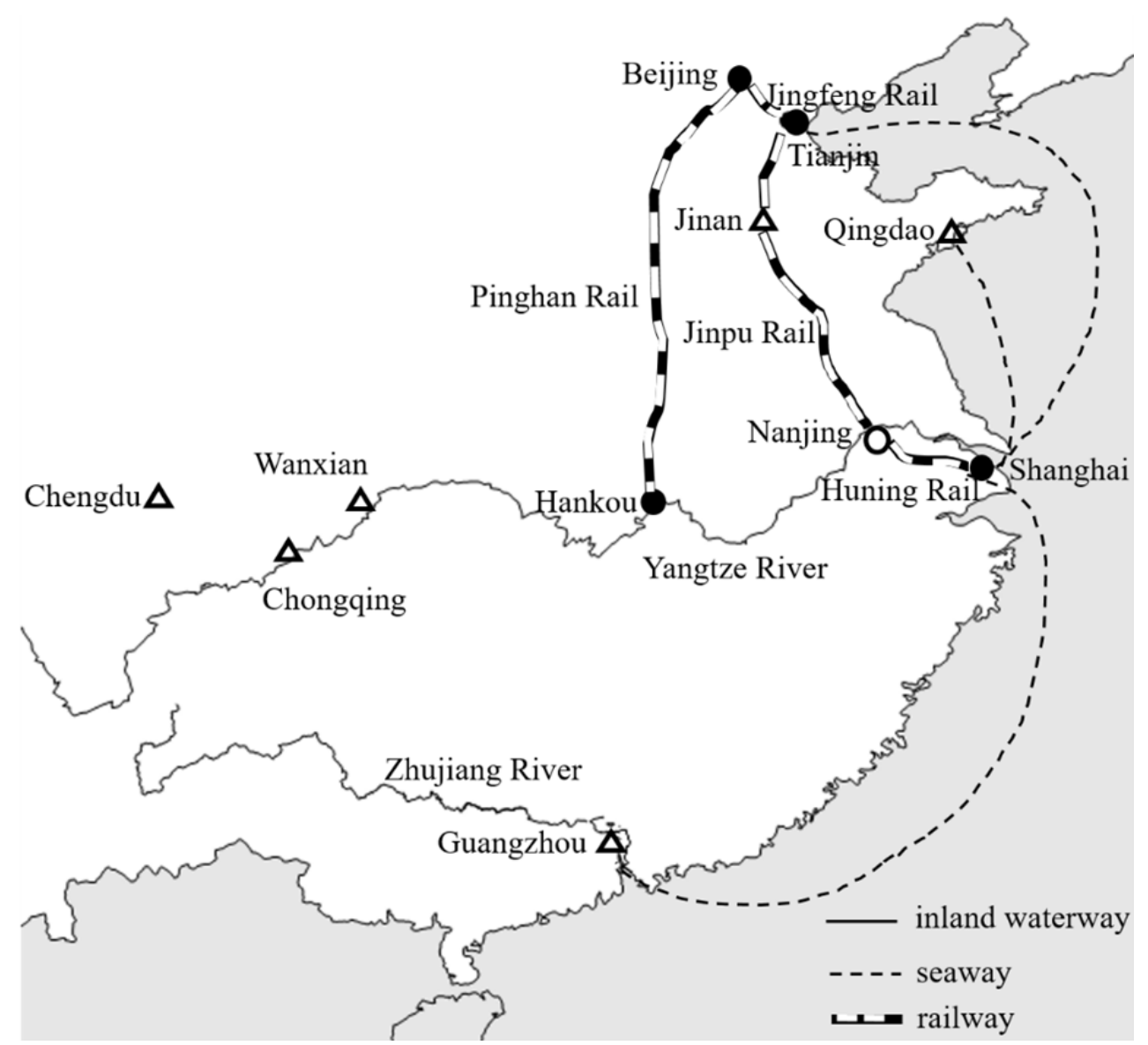

Note: The black circles represent the locations of major commercial centers in Central and North China which we consider in this section, while triangles show our sample of smaller or more remote sample cities that we will consider below. The capital from 1928, Nanjing, is shown with a white circle.

Source: Drawn by authors based on Zhongguo jingnei tielu quantu (Railway map in China), Zhonghua Gongchengshi Xuehui Huibao (Journal of the Chinese Institute of Engineers), 1917 vol. 4 (12), p.1.

Our dataset on domestic exchange rates is drawn from the Shenbao Newspaper, an influential daily newspaper produced during the time of the Republic of China, and the Economic Statistics, an official journal published by the Shanghai Bankers' Association. Our series for the ShanghaiTianjin and Shanghai-Hankou exchange rates span from the moment daily data starts in May 1, 1920 to March 9, 1933 ${ }^{18}$ The sample period ends in 9 March, 1933 because domestic exchange markets in Shanghai were closed off by the abolition of the sycee and tael system (implemented on March 10) ${ }^{19}$ For the Shanghai-Hankou series, the sub-period from April 19, 1927 to March 23, 1928 is excluded, as the Shanghai-Hankou exchange market was closed due to the Northern Expedition ( $\mathrm{Yu}, 1928)$. The period of the Jiangsu-Zhejiang War, which started on September 3

\footnotetext{
${ }^{18}$ The daily data from May 1, 1920 to December 31, 1922 is taken from the Shenbao Newspaper, and the data after January 1, 1923 from the Economic Statistics

${ }^{19}$ The abolition of the sycee and tael system meant that future transactions must be expressed in a new silver currency (the national dollar) subjected to government regulation. It was an important step towards currency unification, but China remained on a silver standard.
} 
and ended on October 13, 1924, is also excluded from the Shanghai-Hankou series ${ }^{20}$ The daily data for the Shanghai-Beijing exchange rates are only available for the period from May 1923 to December 1931. After discarding non-trading days, at our disposal we have 3,687, 3,385 and 2,514 daily observations for Shanghai-Tianjin, Shanghai-Hankou and Shanghai-Beijing exchange rates respectively.

Here we define the parity ratio $e_{i}^{p a r}$ as the ratio of the fixed metallic contents of silver in local taels of port $i$ to the ST. One problem regarding the parity is that the silver content of each tael was not defined by law, but was instead determined by custom and tradition. There are therefore different figures in the literature regarding the exact pure silver content of various taels (Young, 1931). The silver content of the ST recognized in most modern transactions is 518.512 troy grains of pure silver. This was also accepted by the Shanghai Foreign Exchange Bankers Association to be used by its members ${ }^{21}$

Figure 2 depicts the deviation (in percent) of the exchange rate from parity for Tianjin $\left(x_{T, t}\right)$, Hankou $\left(x_{H, t}\right)$ and Beijing $\left(x_{B, t}\right)$, respectively paired with Shanghai. We denote $x_{i, t}$ as the exchange rate deviation (in percent) from parity: $x_{i, t}=100 \ln \left(\frac{e_{i, t}}{e_{i}^{p a r}}\right)$, for $i=T, H, B$, where $e_{i, t}$ is the market exchange rate between Shanghai and city $i$ at time $t$, and $e_{i}^{\text {par }}$ is the corresponding parity. A value of zero for $x_{i, t}$ corresponds to the strong form of the law of one price. But some deviations from parity are to be expected, given frictions in the form of information and trading costs. The dynamics of $x_{i, t}$ will be the object of this paper. The maximum deviation from parity over the full period was slightly over $2 \%$, but this is rarely observed apart from 1927, when a ban on silver exports from Shanghai was enforced during the period of the Northern Expedition. Apart from this period, we note that the deviation from parity was generally constrained within the bounds of $\pm 1 \%$. Taken at face value, this movement implies either that the war presented enhanced arbitrage opportunities or that trading costs grew considerably in response to hostilities. This indicates a possible decline in the degree of monetary market integration during the war. Still, it is clear that $x_{i, t}$ does not exhibit explosive behavior for any $i$. The mean and standard deviation of exchange rate deviations are shown in Table 32 The mean of the deviation is $0.28 \%$ for Shanghai-Tianjin exchange rate (from parity) and is almost zero for Shanghai-Hankou and Shanghai-Beijing exchange rate. However, the table

\footnotetext{
${ }^{20}$ The Jiangsu-Zhejiang War impacted the exchange market between Shanghai and Hankou more directly as it cut off the Yangtze River route. With the onset of war, "the sailing between Woosung and Kiangyin, which is considered the most risky, has already been suspended practically by all steamship companies" (China Press 1924. p.12); see also (Chung Hwa English Weekly, 1924, p.532). In contrast, the seaway between Shanghai and Tianjin were relatively unaffected. Thus, this period are included in the sample period of the Shanghai-Tianjin and the Shanghai-Beijing series. As a robustness exercise, we also re-estimated our model excluding the war period from these two series, and the results remain similar.

${ }^{21}$ As one ounce of pure silver contains 480 troy grains, one ST contained 1.08023 ounces of pure silver at parity (Young, 1931, Wu, 1935a). The pure silver content of the TT was 547.103 troy grains. Thus the parity ratio between the TT and the $\mathrm{ST}$ was $\mathrm{TT} 1=\mathrm{ST} 1.05514(\mathrm{Wu}, 1935 \mathrm{a})$. According to Jin (1925, p. 373), the parity ratio between the HT and TT was 1 Hankou Tael $=1.02450$ Tianjin Taels, and the parity between the HT and the ST was: 1 Hankou Tael $=1.02991$ Shanghai Taels. The parity of the BT and the ST was 1 Beijing Tael $=1.05163$ Shanghai Taels $(\mathrm{Fu}, 1923)$.

${ }^{22}$ Stationarity seems clear from visual inspection, but we also report that the augmented Dickey-Fuller statistics (with intercepts, and lags chosen by the Schwarz criterion), for the $x_{T, t}, x_{H, t}$ and $x_{B, t}$ processes are highly significant at $-6.19,-5.48$ and -4.53 , respectively. The results are substantively similar if linear time trends are also included in the Dickey-Fuller regressions.
} 
also shows clearly that the deviations increased during the period of the Northern Expedition.

Table 3: Summary statistics of exchange rate deviations from parity

\begin{tabular}{|c|c|c|c|c|c|}
\hline & $\begin{array}{r}\text { Exchange } \\
\text { markets }\end{array}$ & $\begin{array}{c}\text { Full period } \\
(05 / 01 / 1920- \\
03 / 09 / 1933)\end{array}$ & $\begin{array}{c}\text { Warlord Era } \\
(05 / 01 / 1920- \\
7 / 08 / 1926)\end{array}$ & $\begin{array}{c}\text { Northern } \\
\text { Expedition } \\
(07 / 09 / 1926- \\
06 / 12 / 1928)\end{array}$ & $\begin{array}{c}\text { Nanjing Era } \\
(06 / 13 / 1928- \\
03 / 09 / 1933)\end{array}$ \\
\hline & $\begin{array}{r}\text { Shanghai- } \\
\text { Tianjin } \\
\left(x_{T, t}\right)\end{array}$ & $0.276(0.601)$ & $0.216(0.488)$ & $0.804(0.609)$ & $0.127(0.613)$ \\
\hline & $\begin{array}{r}\text { Shanghai- } \\
\text { Hankou } \\
\left(x_{H, t}\right)\end{array}$ & $0.003(0.461)$ & $0.171(0.398)$ & $0.330(0.305)$ & $-0.278(0.412)$ \\
\hline & $\begin{array}{r}\text { Shanghai- } \\
\text { Beijing } \\
\left(x_{B, t}\right)\end{array}$ & $-0.111(0.617)$ & $-0.240(0.531)$ & $0.413(0.605)$ & $-0.286(0.529)$ \\
\hline $\begin{array}{l}\text { Notes: } \\
\text { viation } \\
\text { Sources: }\end{array}$ & $\begin{array}{l}\text { This table } \\
\text { of exchange }\end{array}$ & $\begin{array}{l}\text { reports the mean } \\
\text { rate from the } \\
\text { he Shenbao }\end{array}$ & $\begin{array}{l}x_{i, t} \quad \text { (standard d } \\
\text { sponding parity, } \\
\text { Newspaper }\end{array}$ & $\begin{array}{l}\text { tion in parenthes } \\
\text { pressed in percen } \\
\text { the } E\end{array}$ & $\begin{array}{l}x_{i, t} \text { is the de- } \\
\text { e points of parity. } \\
\text { omic }\end{array}$ \\
\hline
\end{tabular}


Figure 2: The percentage deviation of domestic exchange rate from parity, daily data
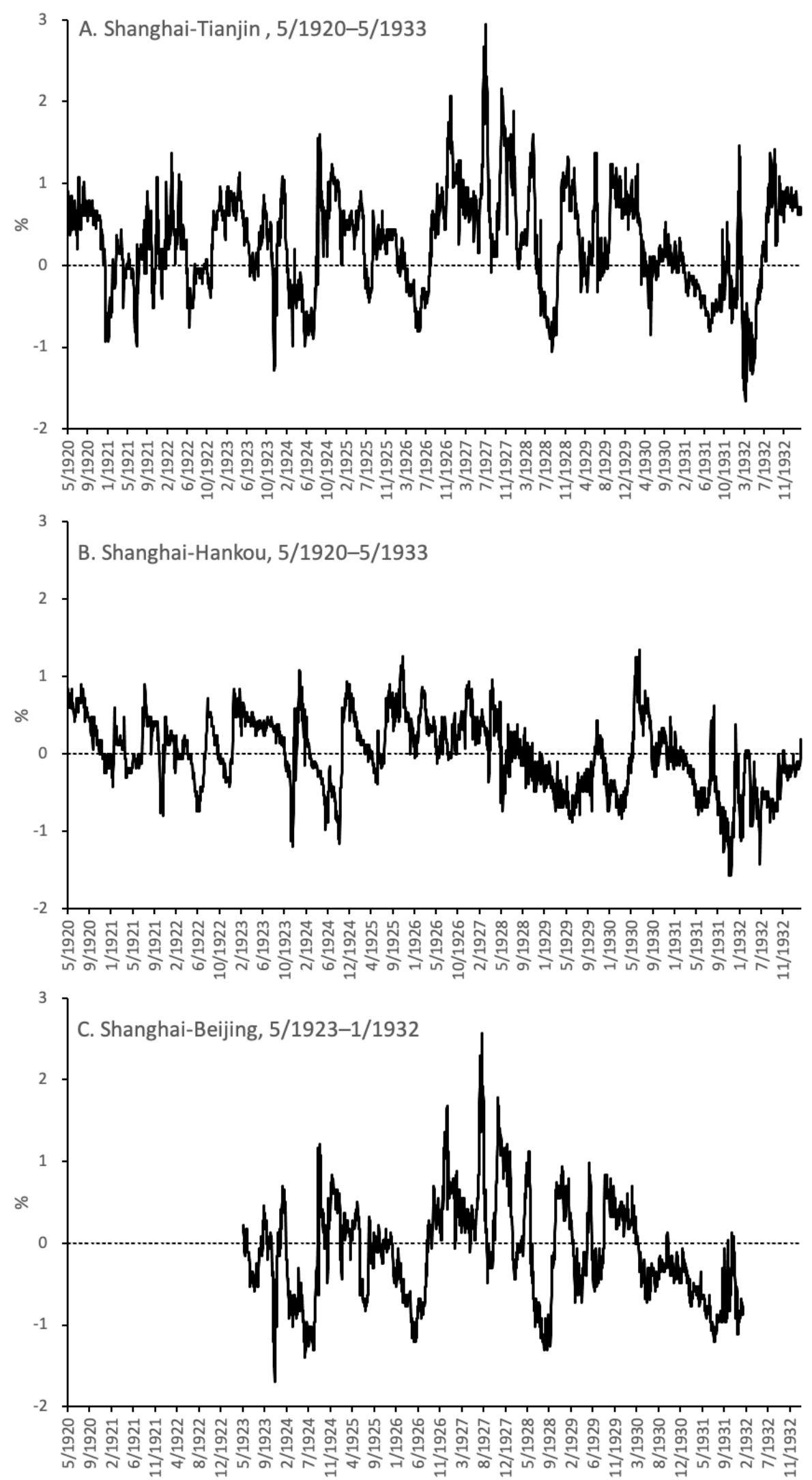

Sources: The Shenbao Newspaper and the Economic Statistics. 


\subsection{Estimation of silver points}

China's silver standard generated a domestic exchange market which was similar to the foreign exchange markets between the gold standard countries. As a result, we are able to rely on the existing literature on gold arbitrage in Western countries. We formalize the mechanism of silver arbitrage with transaction costs with respect to the local historical circumstances in China. As demonstrated in Tables 1 and 2, silver arbitrage suffices to return $x_{i, t}$ back to unprofitable levels of divergence, thereby ensuring it is stationary. But within the range given by the silver points, there were no profitable arbitrage opportunities. Thus $x_{i, t}$ follows a nonlinear process with the speed of mean-reversion toward equilibrium varying with the size of its deviations. This mechanism finds its closest econometric representation in the threshold autoregressive (TAR) model. We estimate the parameters of this system using a three-regime threshold autoregression model which captures all relevant dynamic features and allows us to simultaneously recover the silver points and the speed of adjustment. For each city, we estimate (suppressing the $i$ indicator for simplicity):

$$
x_{t}=\left\{\begin{array}{l}
\beta_{0}^{u}+\sum_{j=1}^{k} \beta_{j}^{u} x_{t-j}+\epsilon_{t} \text { if } x_{t-1}>\theta \\
\beta_{0}^{m}+\sum_{j=1}^{k} \beta_{j}^{m} x_{t-j}+\epsilon_{t} \text { if }\left|x_{t-1}\right| \leq \theta \\
\beta_{0}^{l}+\sum_{j=1}^{k} \beta_{j}^{l} x_{t-j}+\epsilon_{t} \text { if } x_{t-1}<-\theta
\end{array}\right.
$$

where $\beta_{0}^{h}(h=u, m$ or $l)$ are constants, and the innovation $\epsilon_{t}$ is serially uncorrelated. We refer to the estimated thresholds, $\theta$, as 'silver points' in direct parallel to the literature on gold points (Canjels et al. 2004). To operationalize the silver-point arbitrage, we expect that $x_{i, t}$ will revert toward the edge of the band in outer regimes. But within the "corridor" between the two silver points, the change in exchange rate is free to follow a random walk. This model can be estimated using conditional least squares. This entails the use of a grid search to determine the value of the threshold $\theta$, which is implemented as a two-step process. First, using distinct values for the threshold, we estimate each regime using OLS. Second, we minimize the sum of squared residuals over all the values of $\theta$ used.

We estimate the TAR model as in Equation 1 using our daily data. ${ }^{23}$ The lagged order $(k)$ is set to two in order to minimize the value of the Bayesian information criterion (BIC). The results are reported in Table $4{ }^{24}$ For the Shanghai-Tianjin market, the threshold is estimated to be $0.693 \%$, with a $90 \%$ asymptotic confidence interval of $[0.56,0.72]$ calculated using the likelihood ratio approach of Hansen (1997). We cannot reject both the unit root hypothesis in the middle regime and the hypothesis for the outer-regime convergence toward the thresholds. The sum of the AR coefficients in the middle regime is 0.988 , with a half-life of 60 trading days

\footnotetext{
${ }^{23} \mathrm{~A}$ couple of widely used methods for testing linear versus nonlinear models that appear in the literature including the LST test (Luukkonen, Saikkonen, and Teräsvirta, 1988), the Tsay test (Tsay, 1986) and the modified likelihood ratio test (Cryer and Chan, 2008, p.401) - reject linearity for our exchange rate series, suggesting that TAR models are more appropriate than linear models.

${ }^{24}$ For each model, we confine the grid search to threshold values such that each regime has at least five percent the total observations.
} 
(nearly three months). This implies a root close to unity. That is, the middle regime shows barely any convergence. By contrast, the sum of the AR coefficient estimates are 0.951 and 0.898 in the upper and lower regimes, implying that the error correction coefficients are 0.049 and 0.102 , respectively. In words, the half-lives in the upper regime and lower regime are two weeks and one week respectively, validating our model with silver point arbitrage. Moreover, the steady-state values of $x_{T, t}$ are positive in the upper regime and negative in the lower regime, and close to zero in the middle regime, in line with the silver arbitrage mechanism discussed above.

We present the number of observations underlying each regime in the lower panel of the table. Of our 3,685 effective daily observations, the upper regime accounts for 909 observations, a quarter of the total; silver shipments from Shanghai to Tianjin were, therefore, profitable on these days. The lower regime accounts for 208 observations where silver shipments in the opposite direction were profitable 25 The remaining $70 \%$ of total observations represent the middle regime. Here, there are no profitable arbitrage opportunities although the law of one price does not strictly hold, i.e. the deviation from parity is insufficient to cover trading costs. Clearly, exploitable arbitrage opportunities did not persist for long.

For the Shanghai-Hankou market and the Shanghai-Beijing market, the estimates of the silver points are $0.59 \%$ and $0.73 \%$ respectively ${ }^{26}$ Analogously, for each exchange rate series, the middle regime implies a root closer to unity than the two outer-regimes. At the same time, the steady-state values are close to zero in the middle regime. Overall, the estimated silver point was lower in the Shanghai-Hankou markets than the corresponding values of the Shanghai-Tianjin markets and the Shanghai-Beijing markets. These show that, the degree of financial integration across Shanghai and Hankou was higher than that across Shanghai and Tianjin/Beijing. This is in line with expectation as the distance from Hankou to Shanghai is $900 \mathrm{kms}$. In contrast, the distance from Tianjin and Beijing to Shanghai is $1300 \mathrm{kms}$ and 1500 kms, respectively. Moreover, Hankou is connected to Shanghai by the most convenient inland water route in China, the Yangtze River 27

\footnotetext{
${ }^{25}$ We note an asymmetry in the observations encompassed in the upper and lower regimes: silver was more frequently overvalued in Tianjin relative to Shanghai. This result is consistent with Tianjin's net inflow of silver in the Tianjin-Shanghai silver trade. This asymmetry can be attributed largely to the civil strife caused by the North Expedition. Over half of the upper regime days are clustered in the short period of the North Expedition, in particular in the second half of 1927, when the Nationalist Government put on an embargo on silver from Shanghai to Tianjin to prevent the silver in Shanghai from being diverted to the Beiyang warlords. As Tianjin was financially dependent on Shanghai, "this prohibition involved the danger of a serious financial crisis at Tientsin [Tianjin]" (China Press 1927, p.1).

${ }^{26}$ The Shanghai-Hankou market also has local minimum of the sum of squared residuals at $0.24 \%$, which is too low to be credible given the costs of silver trade (see Table 5).

${ }^{27}$ As a robustness exercise we allow for the possibility of asymmetry in trade costs, and we show that the results remain similar in this case (see our Appendix).
} 
Table 4: Results of the TAR model, daily data

\begin{tabular}{|c|c|c|c|}
\hline & $\begin{array}{c}\text { Tianjin } \\
(05 / 1920-03 / 1933)\end{array}$ & $\begin{array}{c}\text { Hankou } \\
(05 / 1920-03 / 1933)\end{array}$ & $\begin{array}{c}\text { Beijing } \\
(05 / 1923-12 / 1931)\end{array}$ \\
\hline$\theta$ & $0.693[0.563,0.715]$ & $0.592[0.545,0.609]$ & $0.727[0.663,0.936$ \\
\hline$\beta_{0}^{u}$ & $0.027(0.015)^{*}$ & $0.046(0.033)$ & $0.026(0.030)$ \\
\hline$\beta_{1}^{u}$ & $0.880(0.030)^{* * *}$ & $0.593(0.058)^{* * *}$ & $0.960(0.045)^{* * *}$ \\
\hline$\beta_{2}^{u}$ & $0.072(0.028)^{* * *}$ & $0.315(0.045)^{* * *}$ & $-0.012(0.040)$ \\
\hline$\beta_{0}^{m}$ & $0.005(0.002)^{* *}$ & $0.000(0.002)$ & $-0.002(0.003)$ \\
\hline$\beta_{1}^{m}$ & $0.762(0.022)^{* * *}$ & $0.860(0.021)^{* * *}$ & $0.849(0.025)^{* * *}$ \\
\hline$\beta_{2}^{m}$ & $0.225(0.021)^{* * *}$ & $0.127(0.020)^{* * *}$ & $0.133(0.025)^{* * *}$ \\
\hline$\beta_{0}^{l}$ & $-0.062(0.040)$ & $-0.008(0.025)$ & $-0.007(0.035)$ \\
\hline$\beta_{1}^{l}$ & $0.866(0.070)^{* * *}$ & $0.834(0.050)^{* * *}$ & $1.031(0.070)^{* * *}$ \\
\hline$\beta_{2}^{l}$ & $0.032(0.063)$ & $0.123(0.043)^{* * *}$ & $-0.055(0.063)$ \\
\hline$\sum_{j=1}^{2} \beta_{j}^{u}$ & 0.951 & 0.908 & 0.948 \\
\hline$\sum_{j=1}^{2} \beta_{j}^{m}$ & 0.988 & 0.987 & 0.982 \\
\hline$\sum_{j=1}^{2} \beta_{j}^{l}$ & 0.898 & 0.957 & 0.976 \\
\hline \multicolumn{4}{|l|}{ Steady-state $x$} \\
\hline $\bar{x}_{i}^{u}$ & 0.555 & 0.497 & 0.511 \\
\hline $\bar{x}_{i}{ }^{m}$ & 0.398 & 0.017 & -0.084 \\
\hline $\bar{x}_{i}^{l}$ & -0.606 & -0.190 & -0.313 \\
\hline $\log (L)$ & 2008.34 & 2554.92 & 1597.27 \\
\hline$\sigma$ & 0.140 & 0.114 & 0.128 \\
\hline \multicolumn{4}{|l|}{ Regime (days) } \\
\hline Upper $(\theta,+\infty)$ & 909 & 340 & 207 \\
\hline Middle $[-\theta, \theta]$ & 2,568 & 2684 & 1858 \\
\hline Lower $(-\infty,-\theta)$ & 208 & 360 & 448 \\
\hline
\end{tabular}

Notes: Standard errors reported in parentheses. A $90 \%$ asymptotic confidence interval of the estimates of threshold reported in brackets. *, **, and *** denote 10\%, 5\%, and 1\% levels of significance, respectively. $\log (L)$ is the log-likelihood value and $\sigma$ is the standard deviation of residuals. "Upper" refers to the number of months for which the deviation exceeds the estimated $(+)$ silver point. "Middle" refers to the number of months for which the deviation is bounded by the estimated $(+)$ and $(-)$ silver point. "Lower" refers to the number of months for which the deviation exceeds in absolute value the estimated (-) silver point. 
3.3. Contemporaneous accounts on silver shipment

Table 5: Costs of silver trade in the Shanghai-Tianjin and Shanghai-Hankou Markets

\begin{tabular}{|c|c|c|c|}
\hline \multicolumn{2}{|c|}{$\begin{array}{c}\text { Shanghai sycee }(100,000 \text { taels }) \text { shipped to } \\
\text { Tianjin }\end{array}$} & \multicolumn{2}{|c|}{$\begin{array}{c}\text { Shanghai sycee }(48,307.84 \text { taels) shipped to } \\
\text { Hankou }\end{array}$} \\
\hline $\begin{array}{l}\text { Charges in } \\
\text { Shanghai }\end{array}$ & $\begin{array}{l}\text { Charges (Shanghai } \\
\text { taels) }\end{array}$ & $\begin{array}{l}\text { Charges in } \\
\text { Shanghai }\end{array}$ & $\begin{array}{c}\text { Charges (Shanghai } \\
\text { taels) }\end{array}$ \\
\hline $\begin{array}{l}\text { Freight }(0.25 \% \text { less } \\
\qquad 5 \% \text { discount })\end{array}$ & 237.5 & Freight & 105.6 \\
\hline $\begin{array}{l}\text { 6-days interest }(5 \% \\
\text { annual rate) }\end{array}$ & 82.38 & Dock dues & 16.04 \\
\hline $\begin{array}{l}\text { Insurance premium } \\
\qquad(0.1 \%)\end{array}$ & 100 & Insurance & 25.5 \\
\hline $\begin{array}{l}\text { Wharfage dues } \\
\qquad(0.03 \%)\end{array}$ & 30 & Carriage & 3 \\
\hline Coolie hire & 5 & Coolie hire & 9.6 \\
\hline Wooden boxes & 27.28 & Wooden boxes & 12 \\
\hline $\begin{array}{c}\text { Charges in } \\
\text { Tianjin }\end{array}$ & & $\begin{array}{c}\text { Charges in } \\
\text { Hankou }\end{array}$ & \\
\hline $\begin{array}{c}\text { Wharfage dues } \\
(0.1 \%)\end{array}$ & 100 & Assay fee & 19 \\
\hline \multirow[t]{2}{*}{$\begin{array}{l}\text { Assay fee and coolie } \\
\text { hire }\end{array}$} & 35 & Coolie hire & 8 \\
\hline & & Ricsha, etc. & 0.21 \\
\hline Total costs & 617.16 (or $0.62 \%$ ) & Total costs & 198.95 (or $0.41 \%$ ) \\
\hline
\end{tabular}

We have estimated silver points based on TAR models. We also noted that that there were few silver point violations across all models. However, these are methods of indirect observation since the silver points are inferred solely through the exchange rate dynamics.

To cross-check the robustness of our estimated silver points, we compare our various estimates of the silver points to contemporaneous accounts. It will be helpful to see that our estimates line up with the shipment costs of silver currency at that time. We first consider the case of Shanghai-Tianjin silver shipment. In our study period, shipping silver sycee from Shanghai to Tianjin could be done by railroad via Nanjing at a cost of $0.625 \%$ (including a freight of $0.585 \%$ and an insurance premium of $0.04 \%$ ), or by steamer, which entailed a cost of $0.54 \%$ (Jin, 1925 , p.21) ${ }^{28}$ Considering further the interest with an annualized rate of $3-5$ percent incurred, the

\footnotetext{
${ }^{28}$ Silver could also be shipped as coins (silver dollars), which was the more costly method for arbitrageurs.
} 
total costs would amount to $0.6-0.7 \%$ (the time of a one-way voyage was about nine days). The costs in the opposite direction were roughly symmetric, as this entailed a transportation cost of $0.585 \%$ for direct shipment or a transportation cost of $0.620 \%$ for forwarding agents (Jin, 1925 , p.231). Kann (1927, p.89) recorded a pro forma note relating to the specific components of the costs specific to Shanghai sycee (100,000 taels) shipped to Tianjin (Table 5), where the total cost of sycee movement was $0.62 \%$. Therefore, the accounts of the two authors are almost identical, and these accounts are close to our silver point estimates for the Shanghai-Tianjin market (that is, $0.693 \%)$.

We next consider the case of Shanghai-Hankou silver shipment. Shipping from Shanghai by steamer to Hankou via the Yangtze River entailed a freight of $0.33 \%$ plus an insurance fee of $0.04 \%$ (Jin, 1925, p.21). When interest is considered, the total transaction costs amounted to around $0.45 \%$. Here an invoice made out on December 9th 1926 and recorded in Kann (1927, p.90) gave a detailed description of the components of cost of silver sycee shipment (Table 5). That date, Shanghai shipped 15 boxes of sycee, amounting to 48,307.842 Shanghai Taels, to Hankou, where the treasure became available (in Hankou Taels) on the 15th December. The shipment costs were 198.95 taels, or $0.41 \%$ of parity, exclusive of interest. When 6 -day interest on an annualized rate of $5 \%$ was included, the total cost was $0.49 \% 29$ That is, contemporaneous accounts across Shanghai and Hankou are very close to our estimates of silver points from the TAR model (0.59\%).

Arguably, our estimates of the silver points for both the Shanghai-Tianjin market and the Shanghai-Hankou market are slightly higher than the reported shipment costs - or at least, they lie in the upper bound of a reasonable range for those. The reason is that in addition to covering direct and interest costs, arbitrageurs required an additional margin to undertake their activity. Their revenues could be adversely affected by events as such as an unduly long voyage, an unexpected loss from re-assay or abrasion of silver, or a delay in collecting an insurance claim for lost silver 30 Overall then, we find that there were no significant informational or policy barriers to the silver currency shipment across China in our study period.

Finally, we consider the costs across Shanghai and Beijing. We found only rough records on the silver movement costs; as Jin (1925, p.21) wrote, "There has been no fixed freight rate [for silver shipment] across Beijing and Shanghai. The shipment costs depend totally on the security situation along the way." Nevertheless, it is possible to make roughly quantitative inference on these costs. Beijing, the neighboring city of Tianjin, was well connected with Tianjin by the Jingfeng Railroad (120 kilometers). The silver movement between Beijing and Tianjin entailed a cost of $0.15 \%$ (Jin, 1925, p.227). The costs for the Shanghai-Beijing silver movement would be slightly higher than for the Shanghai-Tianjin movement. As a result, our estimates of the

Coin shipment between Shanghai and Tianjin could be done by railroad which entailed a cost of $0.74 \%$ (including freight and insurance premium), or by steamer to Tianjin which entailed a cost of $0.76 \%$ (Jin, 1925, pp. 19-21).

${ }^{29}$ The interest loss on silver shipment activity was an opportunity cost, best measured by the daily native interest rate in Shanghai. The average interest rate from 1920 to 1932 was 5.171 percent per year Kong, 1988, pp.478-480).

${ }^{30}$ Naturally, arbitrageurs also required a net profit to undertake gold arbitrage. This was also the case elsewhere; for instance, Officer (1989) estimates that the profit of the gold point arbitrage across New York City and London was $0.125 \%$ of the value shipped. 
silver points are very close to the reported costs.

\section{EXCHANGE RATE EFFICIENCY AND COMPARATIVE DISCUSSION}

We have estimated the silver points between Shanghai and financial sub-centers using TAR models. We also established the reliability of our results by considering the relationship between our indirect measures of silver points, and contemporaneous accounts on the costs of silver shipments. Using the silver point results of the previous section, we are now capable of assessing the efficiency of Chinese domestic exchange markets using two methods. First, we cross-check silver flows and silver-point violations - a term borrowed from Morgenstern's 'gold-point violations' to describe the observations of the exchange rate outside the gold point spread (Morgenstern, 1959). Silver-point violations indicate exploitable arbitrage opportunities. With perfect arbitrage there can be, by definition, no silver-point violations. Under a substantial degree of market integration, silver-point violations could periodically emerge, but would not persist for long as they would immediately cause silver flows via arbitrage. Therefore, we can test for the exchange market efficiency or market integration by investigating silver-point violations and silver flows across cities, as is done in the gold point literature (Goodhart, 1969; Officer, 1996; Canjels et al. 2004). Second, using the silver-points result from the previous section, we calculate the efficiency losses using a variety of measures of the disutility incurred (Officer, 1989). We show that there was a high level of efficiency among the main cities. We then compare our 'silver standard efficiency' with 'gold standard efficiency' estimates for the trans-Atlantic and intra-European exchange market prior to the First World War. We finally turn to the exchange rates for six smaller or more remote cities to present a more nuanced assessment of the degree of Chinese financial integration; we find that more remote cities in South China, including the coastal Guangzhou, were less integrated. Finally, we consider explanations for our findings, outlining the economic factors that reduced barriers to integration between domestic financial markets, such as the growth of the railway network and the developing predominance of the telegraph.

\subsection{Silver-point violations and silver flows}

We have estimated the silver points which favorably match the measured costs of sycee shipments derived from contemporaneous accounts. It should be noted that contemporaneous accounts on the costs of silver shipments are scattered, being specific to certain moments in time. It would be reassuring to cross-validate our results by checking if our silver points do a good job in predicting sycee flows, so as to validate our results and assess the efficiency of domestic exchange markets. For this reason, we have compiled weekly records on sycee flows between Shanghai and outports since 1920. The data from 1920 to the end of 1922 were obtained from the Banker Weekly and the data from 1923 to 1933 from the North-China Daily News. These publications tabulated weekly aggregates of sycee shipments from Shanghai to Tianjin/Hankou, and sycee arrivals to Shanghai from Tianjin/Hankou 31 Note that the figures on sycee flows may not be as informative

\footnotetext{
${ }^{31}$ We have not found silver flow data between Beijing and Shanghai. It seems plausible that sycee flowed from Shanghai to Beijing mainly via Tianjin.
} 
as we wish. Because they are weekly aggregates, the timing of sycee shipments or arrivals is not very precise. Moreover, one has to allow for the lag with which sycee arrived, that is, the days in transit. The lag was likely to be about a week (nine days for the Shanghai-Tianjin shipments and six days for the Shanghai-Hankou shipments).

Nonetheless, we can now present a quantity-based cross-check of our econometric results. In Figure 3, we plot the flow volume of sycee across Shanghai and Tianjin, and the estimated silver points from the TAR model. To allow for the lag with which sycee buying and shipping occurred, we plot in the upper panel the maximum of the exchange rate in the three days before the reporting day of shipments, and in the lower panel the minimum of the exchange rate during the week before the reporting day of arrivals. With circles we indicate on the exchange rate line those days when substantial sycee flows (more than 100,000 Shanghai Taels) were observed. On the bottom of the graph we also show the actual volume of sycee flows. They demonstrate a broad correspondence between particularly large exchange rate deviations and sycee flows: our silver point estimates predict actual silver flows from Shanghai to Tianjin quite well for the entire period. This claim is based on two facts. First, almost all of the large exports to Tianjin occurred when Tianjin exchange deviations were above the estimated thresholds. That is, the rapid and efficient adjustment of the exchange rate under silver point arbitrage kept the domestic exchange rate stable, and any large deviations from parity supposedly provoked silver flows sufficient to push the rate back to within the silver points. This holds true during the Northern Expedition (1926-28) when there was significantly more variation in the exchange rate series and when, presumably, arbitrage opportunities emerged more frequently in the silver market. Second, when the exchange deviation fell below the silver points, the shipment volume of sycee was generally negligible. Arguably, however, the actual silver point during the period of the Northern Expedition might be higher than our estimates. In our econometric models, silver points are assumed to be constant during the entire sample period, but they might have increased during civil wars 32

Only on rare occasions did Shanghai import sycee from Tianjin. The total volume of sycee shipped from Tianjin to Shanghai in the entire period was 3.97 million Shanghai Taels. This was a negligible quantity compared with the volume that went in the opposite direction in the same period - about ten times as much, 39.5 million Shanghai Taels. The reason for such an asymmetry was that most silver was produced in the Americas, and silver imported into China first arrived in Shanghai and then spread to various cities within China. As Kann (1927, p.100) noted, "It is only on rare occasions that Shanghai imports sycee from outports. The principal reason for such eventual imports is a very low outport-Shanghai cross-rate." Even so, these rare imports generally occurred when domestic exchange deviations were below the estimated silver points. Overall, by volume, $97 \%$ of silver flows in this period occurred with silver-point violations, and only $3 \%$ of flows occurred within the corridor between the two points. Except

\footnotetext{
${ }^{32}$ We also estimate the TAR model using only the sub-period of the Northern Expedition, 1 July $1926-29$ Dec. 1928. The estimates of silver points across Shanghai and Tianjin are around $0.6 \%$, hence even smaller than those from the entire period. However, the results are less reliable due to a small sample size. In fact, when we use a longer sub-period before the end of Northern Expedition - from 5 May 1920 to 29 Dec. 1928 — the estimated silver points are almost the same as those from the entire period.
} 
for the two years of the Northern Expedition, it appears that we have estimated both the silver export point and the import point correctly, although there are a couple of peaks that show no sycee flows.

Figure 4 shows the sycee flow between Shanghai and Hankou, and the corresponding estimates of silver points. By volume, $16 \%$ of silver flows in this period occurred within the corridor between the estimated silver points, and $84 \%$ of flows occurred with silver point violations. Nonetheless, we also note a few observations where the exchange rates were actually within the bounds of silver points but with substantial sycee shipment. There are two possible explanations for such an inconsistency. First, as mentioned before, the timing of sycee shipments or arrivals is not very precise. Second, in some cases sycee could be shipped for reasons other than arbitrage. As $\operatorname{Kann}$ (1927, p.87) wrote, "Shipments of sycee are made either in settlement of trade balances or, at times, sycee is shipped for the requirements of provincial Mints." In any case, isolated observations must be viewed with caution and only general patterns can be considered relevant. 
Figure 3: The domestic exchange rate, silver point and silver flows across Shanghai and Tianjin, May 1920-March 1933
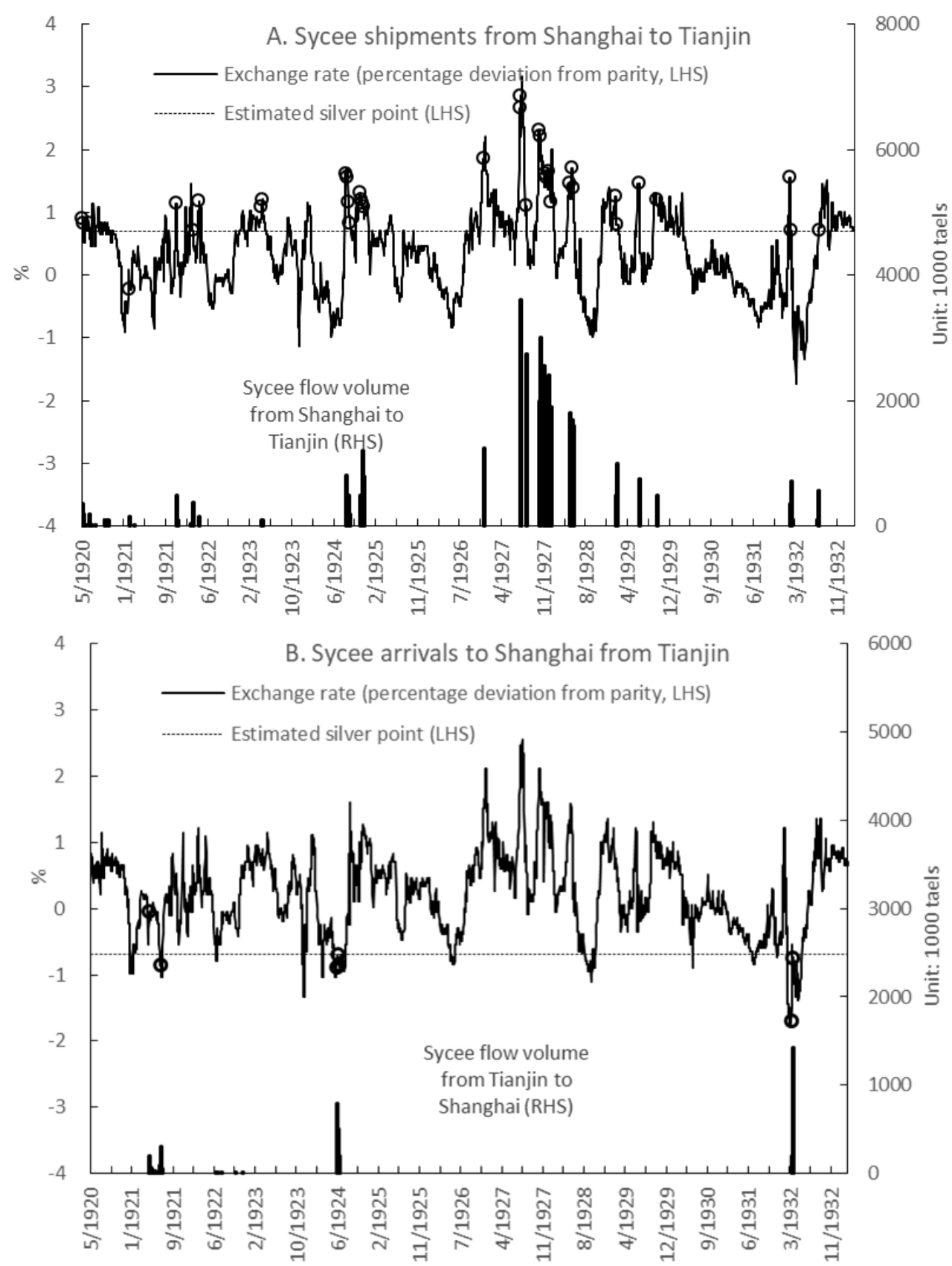

Note: The estimated silver points are from the TAR model using daily data ( $\pm 0.693 \%)$. The solid lines plot the maximum (upper figure) and minimum (lower figure) domestic exchange rate from 7 days until 2 days before the end of the reporting week. With circles we indicate those days when sycee flow volume larger than 100,000 Shanghai taels were observed. On the bottom of the graph we also show the actual volume of the flows.

Sources: Daily exchange rate in Shanghai taken from the Shenbao Newspaper and the Economic Statistics (various issues); silver flow volume taken from the Banker Weekly and the North-China Daily News. 
Figure 4: The domestic exchange rate, silver point and silver flows across Shanghai and Hankou, May 1920-March 1933

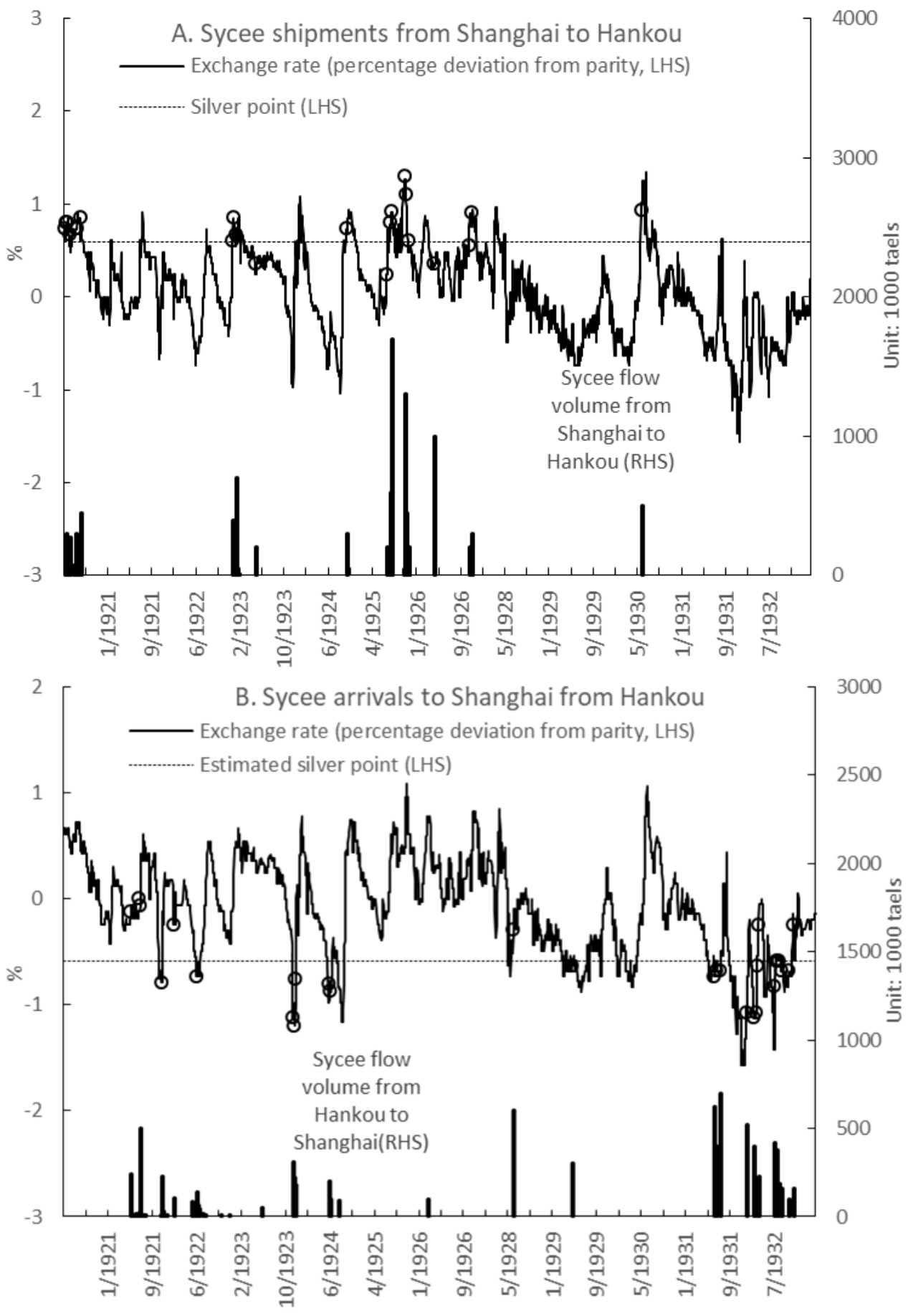

Note: The estimated silver points are from the TAR model using daily data ( $\pm 0.592 \%)$. The 'exchange rate' line plots the maximum (upper figure) and minimum (lower figure) domestic exchange rate from 7 days until 2 days before the end of the reporting week. With circles we indicate those days when sycee flow volume larger than 100,000 Shanghai taels were observed. On the bottom of the graph we also show the actual volume of the flows.

Sources: Daily exchange rates is taken from the Shenbao Newspaper and the Economic Statistics (various issues); silver flow volume taken from the Banker Weekly and the North-China Daily News. 


\subsection{Loss from exchange-rate inefficiency}

We now follow the lead provided by Officer (1989) to measure the efficiency of the silver standard. One of the key insights for the model is that disutility occurs from violations of the 'law of one price'. That is, the loss from market inefficiency should be a function of the deviation of the exchange rate from parity, as under conditions of perfect market efficiency, no arbitrage opportunities can exist and the exchange rate would always be kept at parity.

Denote $\theta$ (and $-\theta$ ) the silver-export point (and silver-import point) for Shanghai. By definition, the silver-point spread is $2 \theta \longdiv { 3 3 }$ Perfect silver point arbitrage would act to keep the exchange rate within the silver-point spread, that is, $|x| \leq \theta$. Denote $u(x)$ as the loss function relating the disutility from market inefficiency to $x$, the deviation from parity. We use three fundamental loss functions in the empirical part of the study: the identity $(u=|x|)$, square $\left(u=x^{2}\right)$, and exponential $\left(u=e^{|x|}-1\right){ }^{34}$ These loss functions involve disutility increasing at rates $(1,2|x|$, and $\left.e^{|x|}\right)$ as $|x|$ increases. Unlike the identity function, the square and exponential functions heavily penalize exchange-rate deviations the further they are from the parity. The average experienced loss from market inefficiency is $\bar{u}=\sum \frac{u}{T}$, where $T$ is the number of observations.

This average experienced loss will be compared with the hypothetical disutility arising from perfect arbitrage, which implies that the exchange rate is always within the spread. Assume that, in the hypothetical case, over a sufficiently long period the exchange rate takes on values within the silver spread with equal probability. Therefore, $x$ follows the uniform distribution within the silver-point spread. The hypothetical expected loss from market inefficiency is:

$$
E(u)=\frac{1}{\theta} \int_{0}^{\theta} u(x) d x
$$

For the identity, square and exponential functions of $u$, the computed values of $E(u)$ are $\frac{\theta}{2}, \frac{\theta^{2}}{3}$ and $\frac{e^{\theta}-\theta-1}{\theta}$, respectively. Thus we define a measure of exchange-market efficiency, the efficiency ratio, as $\frac{\bar{u}}{E(u)}$, that is, the experienced average loss from market efficiency during a given sample period relative to the hypothetical expected loss of perfect arbitrage. One may naturally expect this ratio to be greater than 1 , due to the fact that violations of the silver points are impossible in the hypothetical situation of perfect arbitrage, in contrast to the reality of frequent silver-point violations. Nevertheless, there is every likelihood that this ratio lies below unity, due to exchange-rate speculation (Officer, 1989).

We can now calculate the efficiency ratio $\frac{\bar{u}}{E(u)}$ using Equation 2, that is, the sample mean disutility during the sample period relative to the hypothetical expected loss of perfect silverpoint arbitrage. For the Shanghai-Tianjin market and the identity loss function, $|x|$, the average experienced loss is the average percentage deviation (in absolute values) of the exchange rate from the parity, computed over all the daily observations of the respective period. It is 0.531 for

\footnotetext{
${ }^{33}$ The silver-point spread is defined as the difference between silver-export point and the silver-import point, analogous to the gold standard literature (Officer, 1989). Efficient silver point arbitrage would act to keep the domestic exchange rate within the silver-point spread.

${ }^{34}$ As noted by Officer 1989$)$, properties of $u(x)$ should include: $u(0)=0 ; u(x)>0$, for $x \neq 0 ; u(x)=u(-x)$; and $u(x)$ being continuously differentiable.
} 
the full period. Under perfect silver-point arbitrage, the average hypothetical disutility under the identity loss function is simply half the magnitude of a silver point. With the silver point defined being 0.693 percent of parity for the Shanghai-Tianjin markets, the average hypothetical loss is 0.347 percent. The measure of exchange-market relative efficiency is the ratio of the experienced loss to the hypothetical loss. The results are presented in Table 6. For the full period, the efficiency ratio of 1.53 means that, on average, the exchange rate deviated from parity $53 \%$ more than what would occur under perfect silver arbitrage.

The efficiency ratios are 1.29, 2.43 and 1.47 for three sub-periods-the Warlord Era, the Northern Expedition, and the Nanjing Decade, respectively 35 Not surprisingly, the domestic exchange markets of China experienced substantial efficiency loss during the Northern Expedition. However, the average experienced disutility is similar for the Warlord Era and the Nanjing Era, with efficiency in the Warlord Era even marginally above that in the Nanjing Era ${ }^{36}$ For the Shanghai-Tianjin market, the efficiency ratios for the square and exponential loss functions lead to the same conclusion. The same is true for the Shanghai-Hankou and the Shanghai-Beijing markets 37

\footnotetext{
${ }^{35}$ In all cases the ratio is above unity, as expected. That is, the experienced loss from exchange-market inefficiency exceeds the corresponding hypothetical loss under perfect silver-point arbitrage.

${ }^{36}$ We speculate that the Great Depression in the early 1930s could be a disrupting factor for the efficiency in Nanjing Decade.

${ }^{37}$ The Shanghai-Hankou exchange market was closed from April 19, 1927 to March 23, 1928 due to the proximity of Hankou to the battlefields of the Northern Expedition. Therefore, our Table 6 does not present average experienced losses (which must have been large) of the Shanghai-Hankou market for the sub-period of the Northern Expedition.
} 
Table 6: Loss from the inefficiency of domestic exchange markets

\begin{tabular}{|c|c|c|c|c|c|c|c|c|c|}
\hline \multirow[b]{2}{*}{$\begin{array}{c}\text { Loss } \\
\text { Function }\end{array}$} & \multicolumn{4}{|c|}{ Average experienced loss } & \multirow{2}{*}{$\begin{array}{c}\text { Average } \\
\text { hypotheti- } \\
\text { cal } \\
\text { loss }\end{array}$} & \multicolumn{4}{|c|}{ Efficiency ratio } \\
\hline & $\begin{array}{l}\text { Full Period } \\
(5 / 01 / 1920- \\
3 / 09 / 1933)\end{array}$ & $\begin{array}{c}\text { Warlord } \\
\text { Era } \\
(5 / 01 / 1920- \\
7 / 08 / 1926) \\
\end{array}$ & $\begin{array}{l}\text { Northern } \\
\text { Expedition } \\
(7 / 09 / 1926- \\
6 / 12 / 1928) \\
\end{array}$ & $\begin{array}{c}\text { Nanjing } \\
\text { Era } \\
(6 / 13 / 1928- \\
3 / 09 / 1933) \\
\end{array}$ & & $\begin{array}{l}\text { Full Period } \\
(5 / 01 / 1920- \\
3 / 09 / 1933)\end{array}$ & $\begin{array}{c}\text { Warlord } \\
\text { Era } \\
(5 / 01 / 1920- \\
7 / 08 / 1926) \\
\end{array}$ & $\begin{array}{l}\text { Northern } \\
\text { Expedition } \\
(7 / 09 / 1926- \\
6 / 12 / 1928) \\
\end{array}$ & $\begin{array}{c}\text { Nanjing } \\
\text { Era } \\
(6 / 13 / 1928 \\
3 / 09 / 1933) \\
\end{array}$ \\
\hline \multicolumn{10}{|c|}{ Shanghai-Tianjin } \\
\hline$|x|$ & 0.531 & 0.447 & 0.845 & 0.508 & 0.347 & 1.532 & 1.290 & 2.429 & 1.467 \\
\hline$x^{2}$ & 0.437 & 0.286 & 1.016 & 0.392 & 0.160 & 2.733 & 1.784 & 6.350 & 2.450 \\
\hline$e^{|x|}-1$ & 0.866 & 0.636 & 1.773 & 0.783 & 0.443 & 1.956 & 1.437 & 4.002 & 1.767 \\
\hline \multicolumn{10}{|c|}{ Shanghai-Hankou } \\
\hline$|x|$ & 0.377 & 0.356 & - & 0.401 & 0.296 & 1.272 & 1.203 & - & 1.356 \\
\hline$x^{2}$ & 0.213 & 0.188 & - & 0.248 & 0.117 & 1.826 & 1.610 & - & 2.122 \\
\hline$e^{|x|}-1$ & 0.514 & 0.474 & - & 0.566 & 0.364 & 1.412 & 1.303 & - & 1.556 \\
\hline \multicolumn{10}{|c|}{ Shanghai-Beijing } \\
\hline$|x|$ & 0.511 & 0.459 & 0.570 & 0.523 & 0.369 & 1.385 & 1.245 & 1.545 & 1.417 \\
\hline$x^{2}$ & 0.393 & 0.339 & 0.536 & 0.360 & 0.182 & 2.163 & 1.866 & 2.953 & 1.985 \\
\hline$e^{|x|}-1$ & 0.797 & 0.696 & 1.011 & 0.765 & 0.479 & 1.662 & 1.452 & 2.109 & 1.597 \\
\hline
\end{tabular}

Shanghai-Hankou exchange market was closed from April 19, 1927 to March 23, 1928, due to the proximity of Hankou to the battlefields of the Northern Expedition. Hence this table does not present the results from the Shanghai-Hankou market for the sub-period of the Northern Expedition. Sources: See the discussion of the model in the text. 
A natural question at this juncture is the extent to which these results can be compared to the more well-known "gold standard efficiency". Using the same three loss functions, Officer (1989) estimates that the trans-Atlantic gold-point was $0.654 \%$ and the efficiency ratio was below unity (around 0.86) for the period of 1890-1906. Therefore, gold arbitrageurs and exchange-rate speculators jointly contributed to market efficiency. If this conclusion is tenable, the Chinese silver-standard efficiency was below that of the gold standard. However, there is evidence that Officer's gold point was too high. Canjels et al. (2004) show a decline of gold points from $0.419 \%$ to $0.249 \%$ from 1879 to 1913 , with a mean of about $0.334 \%$. In turn, Spiller and Wood (1988) estimate gold points of around $0.25 \%$ for the period of 1899-1908. Officer himself re-estimates these at around $0.35 \%$ for the period from 1900 to 1906 (Officer, 1996, p.235). When $0.35 \%$ is taken as the baseline, the efficiency ratios of Dollar-Sterling for the period of 1890-1906 are 1.72, 3.33 and 1.95 for the identity, square and exponential loss functions, respectively, hence similar in magnitude to our results for the Chinese silver standard. In a few cases, silver-standard efficiency was even marginally greater than gold-standard efficiency

Finally, how well integrated were the domestic exchange markets of China in the early twentieth century compared with Europe in other periods? Our estimates of silver points are well below the transaction costs associated with arbitrage in late medieval and early modern Europe. For instance, in the sixteenth-century, the transaction costs associated with currency arbitrage are estimated to have been 4.4 and 6 percent for the London-Antwerp exchange markets and the Seville-Medina del Campo markets, respectively ( $\mathrm{Li}, 2015)$. It is natural to expect that the costs would be even higher in earlier times: in 1385-1450, they are estimated to have been $34 \%$ and $99 \%$ for the Flanders-Lübeck markets and the Flanders-Prussia markets, respectively (Li, 2015). While different in magnitude, these pairs of estimates are not exactly comparable with our results as they are for different metallic currencies and for different distances. But what they emphasize is that the invention of the telegraph in the nineteenth century reduced the time needed for communication to a negligible level, greatly enhancing market integration (Hoag, 2006; Steinwender, 2018).

\subsection{Extension: smaller or more remote cities}

We have found that monetary market integration between Shanghai and China's three major economic hubs (Tianjin, Hankou and Beijing) was remarkably high even by the standards of Western economies in the early twentieth century. For these cities, daily exchange rates are available over long periods given their commercial importance. However, all three are located in northern and central China, an economically developed area well linked by railways or waterways. Therefore, the results may not be representative nationally, and should be interpreted as an upper bound of the financial integration of the national level. In order to better understand the

\footnotetext{
${ }^{38}$ While the estimates of the contemporaneous gold points between London and New York City vary across sub-periods and estimation methods, all of them are lower than estimates of the silver points between Shanghai and Tianjin. For two reasons, we suggest that the levels of silver point and gold point are not comparable, and only the efficiency ratio is relevant. First, there are the physical characteristics of gold versus silver. Silver had a lower value-to-weight ratio than gold, so that shipping costs for silver were about 2 to 3 times higher than those for gold. Second, there are the geographical characteristics of the cities involved in the two trades. The distance from New York City to London is five times the distance from Tianjin to Shanghai, for instance.
} 
extent to which these cities may be over-representing the degree of national integration, we now include additional cities in our analysis. The exchange rates for these smaller or more remote cities contrast to those of the major trading centers and enable us to present a more nuanced assessment of financial integration at the national level. We find that the level of Shanghai's integration with small cities located in the north of the country was also high, but the same was not the case for more remote cities located in the Southeast and Southwest, including the large coastal city of Guangzhou which was not under government control.

For our additional cities the extant data on exchange rates are spotty or only available for shorter sub-periods. Nonetheless, we can present an analogous exercise to that of before. Given the sample size required for meaningful time series analysis, we restrict our analysis to cities with exchange rate data (paired with Shanghai) which span over three years. Our expanded dataset includes two cities in the Shandong province, North China: Jinan (data available for Aug. 1921-Dec. 1924) and Qingdao (Aug. 1921-Dec. 1925); three cities in Southwest China (Sichuan province): Chongqing (Aug. 1921-Dec. 1929), Wanxian (Aug. 1921-Dec. 1929) and Chengdu (Aug. 1921-April 1926); and one city in Southeast China: Guangzhou (Aug. 1925-Dec. 1931) ${ }^{39}$ Our dataset for these six cities is drawn mainly from the Shibao Newspaper, supplemented by the Shenbao Newspaper and the Economic Statistics ${ }^{40}$ Due to the unavailability of data for a significant number of trading days, we use weekly-frequency observations in this exercise, using the exchange rate of the last trading day of each week (typically Saturday).

Figure 5 depicts the deviation of the exchange rate from parity for each city (paired with Shanghai) ${ }_{41}^{41}$ For both cities in North China — Jinan and Qingdao — we note that the maximum deviation was about $2 \%$, similar in amplitude to the exchange rates of the three major commercial hubs as shown in Figure 2. (For Qingdao, accessible through a convenient seaway, the deviation was generally constrained within the bounds of 1\%.) However, the situation in the remote southeast and southwest cities tells a different story, as the magnitudes of deviations are larger and persist for longer.

\footnotetext{
${ }^{39}$ Of these, the four cities can be considered remote: those in the Sichuan province in Southwest China (Chengdu, Chongqing and Wanxian), as well as Guangzhou, a large city in Guangdong. Neither were under governmental control and each region had its own silver-based currency. The two cities in North China in our sample (Jinan and Qingdao) were not remote, as they were closer to Shanghai, but they were smaller than the major hubs that we have considered previously.

${ }^{40}$ The Shibao Newspaper (Eastern Times), positioned as "the Times of the East", was a daily newspaper published in Shanghai and popular in intellectual circles.

${ }^{41}$ The parity ratios between the Shanghai Tael and other local taels were 1 Jinan Tael $=1.030$ Shanghai Taels, 1 Qingdao Tael $=1.067$ Shanghai Taels, and 1 Guangzhou dollar $=0.6335$ Shanghai Taels (Economic Statistics, July 1923, p. 30). Contemporaneous accounts vary greatly regarding the parity of the taels used in Sichuan province. Some authors held that a common tael, the Chuanping tael, was used in the whole province, including Chongqing, Chengdu and Wanxian, with the parity of 1 Chuanping Tael = 1.0534 Shanghai Taels; see Jin (1925. p.448) and $\mathrm{Su}(1921, \mathrm{p} .181)$. But others held that the taels in these three cities were of different silver contents, although having the same names (Economic Statistics, July 1923, p. 30). Therefore, we use the sample average of market exchange rate as an alternative for the corresponding parity in each city Sichuan province.
} 
Figure 5: The percentage deviation of exchange rate from parity, weekly data

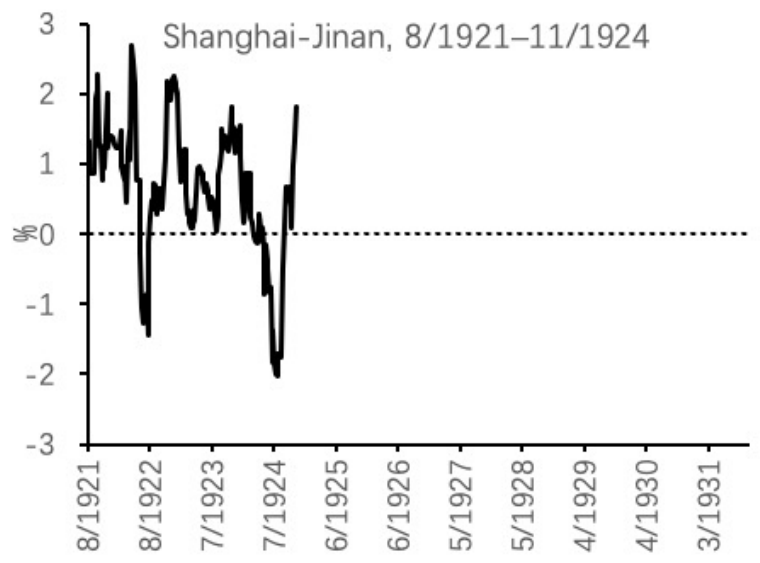

North China

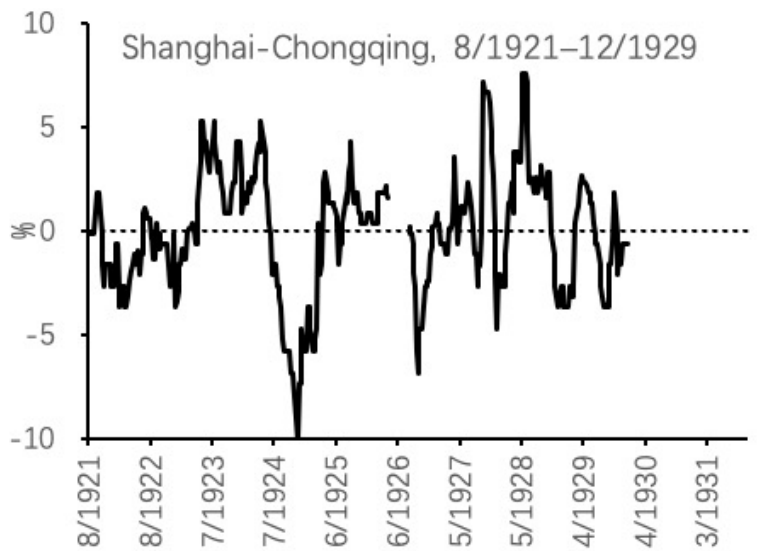

Southwest China

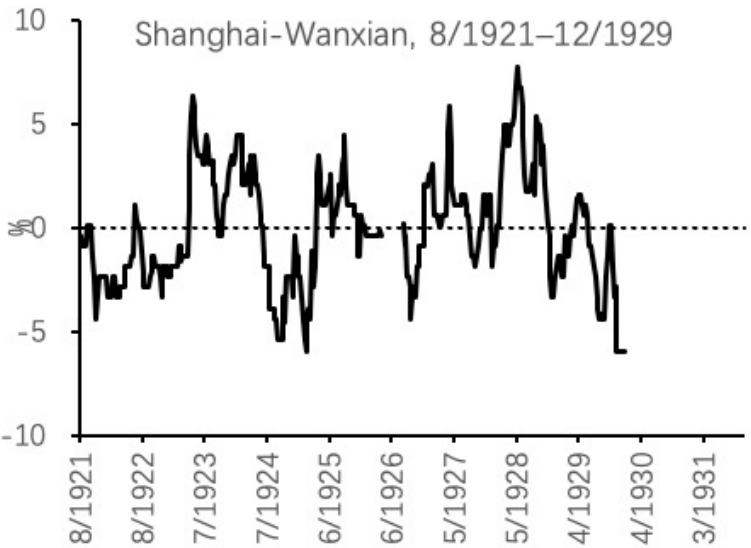

Southwest China

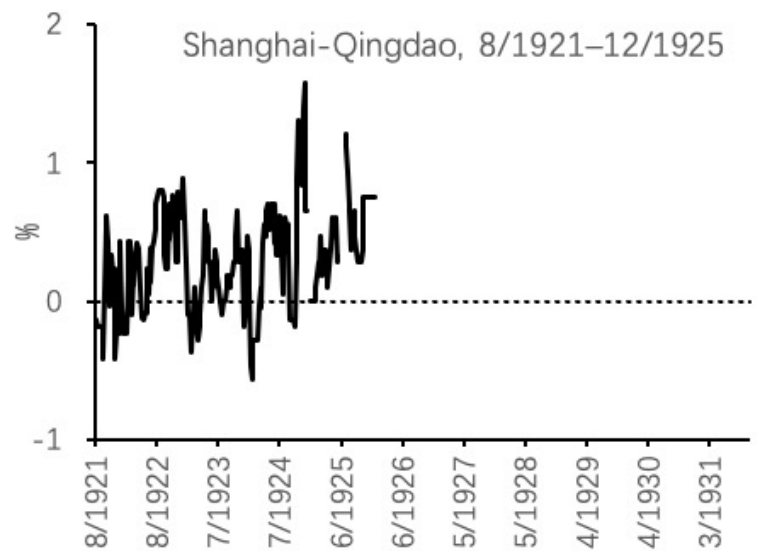

North China

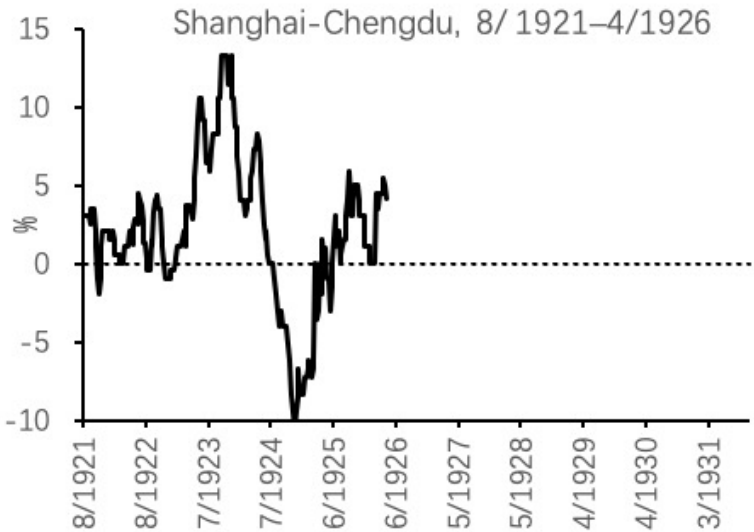

Southwest China

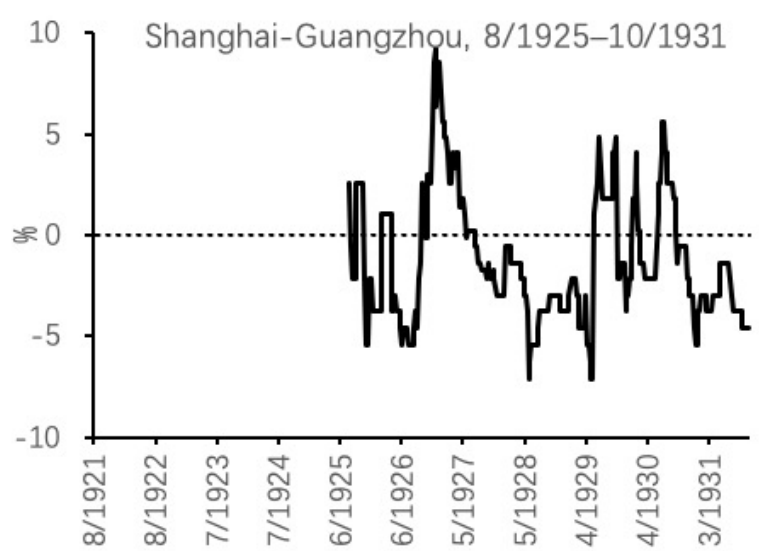

Southeast China

Notes: The percentage deviation of exchange rate from parity is defined as: $x_{i, t}=100 \ln \left(e_{i, t} / e_{i}^{\text {par }}\right)$, where $e(i, t)$ is the exchange rate for city $i$, and $e_{i}^{p a r}$ is the parity, paired with Shanghai. Since $e(i, t)$ is quoted as the number of the Shanghai Tael for a unit of city $i^{\prime} s$ currency, a positive value of $x_{i, t}$ suggests that city $i^{\prime} s$ currency is overvalued in the exchange market while a negative value of $x_{i, t}$ suggests that it is undervalued.

Data sources: The Shibao Newspaper, the Shenbao Newspaper and the Economic Statistics 
We now estimate the threshold model as in Equation (1) using weekly data for these cities. The results are reported in Table 7 . We choose the lagged order $k=1$ or 2 to minimize the BIC. In order to ensure strict comparability of results between these smaller or remote areas and major commercial hubs, we also present the results of Tianjin, Hankou and Beijing using weekly data in this table ${ }^{42}$ Here, the estimates of the thresholds for Tianjin, Hankou and Beijing are $0.81 \%, 0.61 \%$ and $0.68 \%$, respectively, which are close to those generated from the daily data. ${ }_{43}^{43}$ While for Hankou the estimates from both the daily and the weekly data are almost identical, the estimates using weekly data are higher for Tianjin, and lower for Beijing, than those generated from daily data. Nevertheless, for each city the difference between the thresholds from weekly and daily data is merely 0.1 percentage points. This can be taken as a positive indication for the robustness of our previous silver point estimates, as well as for the credibility of the results for the additional cities for which we only have weekly data. As before, the middle regime for each case is estimated to encompass around $80 \%$ of the total observations.

\footnotetext{
${ }^{42}$ We use the last trading day of the week in order to mitigate the caveats about using averages raised by Taylor (2001).

${ }^{45}$ It seems that the threshold for Beijing is somewhat underestimated using weekly data, but note that this estimate also has a relatively large confidence interval.
} 
Table 7: Results of the TAR model, weekly data

\begin{tabular}{|c|c|c|c|c|c|c|c|c|c|}
\hline & $\begin{array}{l}\text { Tianjin } \\
5 / 1920- \\
5 / 1933\end{array}$ & $\begin{array}{l}\text { Hankou } \\
5 / 1920- \\
3 / 1933\end{array}$ & $\begin{array}{l}\text { Beijing } \\
5 / 1923- \\
12 / 1931\end{array}$ & $\begin{array}{l}\text { Jinan } \\
8 / 1921- \\
12 / 1924\end{array}$ & $\begin{array}{l}\text { Qingdao } \\
8 / 1921- \\
12 / 1925\end{array}$ & $\begin{array}{l}\text { Chongqing } \\
8 / 1921- \\
12 / 1929\end{array}$ & $\begin{array}{l}\text { Chengdu } \\
8 / 1921- \\
4 / 1926\end{array}$ & $\begin{array}{l}\text { Wanxian } \\
8 / 1921- \\
12 / 1929\end{array}$ & $\begin{array}{l}\text { Guangzhou } \\
8 / 1925- \\
12 / 1931\end{array}$ \\
\hline$\theta$ & $\begin{array}{r}0.81 \\
{[0.714,} \\
0.872]\end{array}$ & $\begin{array}{l}0.608 \\
{[0.340,} \\
-]\end{array}$ & $\begin{array}{l}0.681 \\
{[0.489,} \\
-]\end{array}$ & $\begin{array}{c}0.604 \\
{[0.487} \\
0.852]\end{array}$ & $\begin{array}{c}0.327 \\
-\end{array}$ & $\begin{array}{c}3.546 \\
-\end{array}$ & $\begin{array}{c}4.037 \\
-\end{array}$ & $\begin{array}{c}3.248 \\
-\end{array}$ & $\begin{array}{c}4.099 \\
-\end{array}$ \\
\hline$\beta_{0}^{u}$ & $\begin{array}{c}0.006 \\
(0.091)\end{array}$ & $\begin{array}{c}0.397^{* *} \\
(0.16)\end{array}$ & $\begin{array}{c}0.260^{* *} \\
(0.12)\end{array}$ & $\begin{array}{l}0.208^{*} \\
(0.107)\end{array}$ & $\begin{array}{c}0.013 \\
(0.062)\end{array}$ & $\begin{array}{l}-0.199 \\
(0.627)\end{array}$ & $\begin{array}{c}0.066 \\
(0.348)\end{array}$ & $\begin{array}{l}-0.095 \\
(0.514)\end{array}$ & $\begin{array}{l}-0.529 \\
(0.762)\end{array}$ \\
\hline$\beta_{1}^{u}$ & $\begin{array}{c}0.885^{* * *} \\
(0.076)\end{array}$ & $\begin{array}{l}0.386^{*} \\
(0.198)\end{array}$ & $\begin{array}{c}0.662^{* * *} \\
(0.11)\end{array}$ & $\begin{array}{c}0.850^{* * *} \\
(0.113)\end{array}$ & $\begin{array}{c}0.852^{* * *} \\
(0.095)\end{array}$ & $\begin{array}{c}1.120^{* * *} \\
(0.145)\end{array}$ & $\begin{array}{c}1.139^{* * *} \\
(0.116)\end{array}$ & $\begin{array}{c}1.293^{* * *} \\
(0.158)\end{array}$ & $\begin{array}{c}1.034^{* * *} \\
(0.198)\end{array}$ \\
\hline$\beta_{2}^{u}$ & - & - & - & $\begin{array}{l}-0.05 \\
(0.101)\end{array}$ & - & $\begin{array}{l}-0.179^{*} \\
(0.109)\end{array}$ & $\begin{array}{l}-0.166 \\
(0.108)\end{array}$ & $\begin{array}{c}-0.359^{* * *} \\
(0.114)\end{array}$ & $\begin{array}{l}-0.053 \\
(0.152)\end{array}$ \\
\hline$\beta_{0}^{m}$ & $\begin{array}{c}0.018 \\
(0.012)\end{array}$ & $\begin{array}{l}-0.004 \\
(0.009)\end{array}$ & $\begin{array}{l}-0.005 \\
(0.014)\end{array}$ & $\begin{array}{c}0.026 \\
(0.068)\end{array}$ & $\begin{array}{c}0.073 \\
(0.022)\end{array}$ & $\begin{array}{c}0.013 \\
(0.055)\end{array}$ & $\begin{array}{c}0.125 \\
(0.116)\end{array}$ & $\begin{array}{l}-0.017 \\
(0.05)\end{array}$ & $\begin{array}{c}-0.05 \\
(0.088)\end{array}$ \\
\hline$\beta_{1}^{m}$ & $\begin{array}{c}0.976 \\
-0.026\end{array}$ & $\begin{array}{c}0.949^{* * *} \\
(0.027)\end{array}$ & $\begin{array}{c}0.905^{* * *} \\
(0.038)\end{array}$ & $\begin{array}{c}1.536^{* * *} \\
(0.276)\end{array}$ & $\begin{array}{c}0.999^{* * *} \\
0.127\end{array}$ & $\begin{array}{c}1.135^{* * *} \\
(0.066)\end{array}$ & $\begin{array}{c}0.833^{* * *} \\
(0.096)\end{array}$ & $\begin{array}{c}1.045^{* * *} \\
(0.065)\end{array}$ & $\begin{array}{c}1.010^{* * *} \\
(0.069)\end{array}$ \\
\hline$\beta_{2}^{m}$ & - & - & - & $\begin{array}{c}-0.324^{* *} \\
(0.138)\end{array}$ & - & $\begin{array}{c}-0.179^{* * *} \\
(0.061)\end{array}$ & $\begin{array}{c}0.076 \\
(0.087)\end{array}$ & $\begin{array}{l}-0.054 \\
(0.059)\end{array}$ & $\begin{array}{l}-0.031 \\
(0.063)\end{array}$ \\
\hline$\beta_{0}^{l}$ & $\begin{array}{c}0.127 \\
(0.296)\end{array}$ & $\begin{array}{c}0.028 \\
(0.102)\end{array}$ & $\begin{array}{c}-0.239^{*} \\
(0.128)\end{array}$ & $\begin{array}{l}-0.541 \\
(0.305)\end{array}$ & $\begin{array}{c}0.065 \\
(0.628)\end{array}$ & $\begin{array}{c}0.13 \\
(0.468)\end{array}$ & $\begin{array}{l}-0.246 \\
(0.800)\end{array}$ & $\begin{array}{c}0.175 \\
(0.575)\end{array}$ & $\begin{array}{l}-0.244 \\
(0.739)\end{array}$ \\
\hline$\beta_{1}^{l}$ & $\begin{array}{c}0.766^{* * *} \\
(0.274)\end{array}$ & $\begin{array}{c}0.842^{* * *} \\
(0.126)\end{array}$ & $\begin{array}{c}0.691^{* * *} \\
(0.137)\end{array}$ & $\begin{array}{c}0.011 \\
(0.294)\end{array}$ & $\begin{array}{c}0.899 \\
(1.198)\end{array}$ & $\begin{array}{c}0.909^{* * *} \\
(0.143)\end{array}$ & $\begin{array}{c}1.219^{* * *} \\
(0.264)\end{array}$ & $\begin{array}{c}0.893^{* * *} \\
(0.184)\end{array}$ & $\begin{array}{c}1.112^{* * *} \\
(0.201)\end{array}$ \\
\hline$\beta_{2}^{l}$ & - & - & - & $\begin{array}{c}0.597^{* * *} \\
(0.223)\end{array}$ & - & $\begin{array}{l}0.061 \\
(0.12)\end{array}$ & $\begin{array}{l}-0.288 \\
(0.241)\end{array}$ & $\begin{array}{c}0.087 \\
(0.142)\end{array}$ & $\begin{array}{l}-0.217 \\
(0.185)\end{array}$ \\
\hline$\sum_{i=1}^{2} \beta_{i}^{u}$ & 0.885 & 0.386 & 0.662 & 0.800 & 0.852 & 0.941 & 0.973 & 0.934 & 0.981 \\
\hline$\sum_{i=1}^{2} \beta_{i}^{m}$ & 0.976 & 0.949 & 0.905 & 1.212 & 0.999 & 0.957 & 0.909 & 0.991 & 0.979 \\
\hline$\sum_{i=1}^{2} \beta_{i}^{l}$ & 0.766 & 0.842 & 0.691 & 0.608 & 0.899 & 0.971 & 0.931 & 0.98 & 0.895 \\
\hline $\log L$ & -49.48 & -133.00 & -16.22 & -73.74 & 15.34 & -582.17 & -367.12 & -534.07 & -523.67 \\
\hline$\sigma$ & 0.261 & 0.195 & 0.252 & 0.389 & 0.228 & 0.981 & 1.131 & 0.875 & 1.188 \\
\hline \multicolumn{10}{|l|}{$\begin{array}{l}\text { Regime } \\
\text { (weeks) }\end{array}$} \\
\hline Upper $(0,+\infty)$ & 111 & 53 & 43 & 100 & 108 & 41 & 74 & 55 & 28 \\
\hline Middle $[-\infty,+\infty]$ & 544 & 492 & 327 & 48 & 100 & 327 & 146 & 313 & 252 \\
\hline Lower $(-\infty, 0)$ & 16 & 62 & 75 & 18 & 12 & 52 & 22 & 52 & 53 \\
\hline
\end{tabular}

Note: Standard errors reported in parentheses. A $90 \%$ asymptotic confidence interval of the estimates of threshold reported in brackets. Some confidence intervals are missing because they are too wide and hence fall out of our grid search, indicating inaccurate estimates. *, **, and *** denote $10 \%, 5 \%$, and $1 \%$ levels of significance, respectively. $\log \mathrm{L}$ is the log-likelihood value and is the standard deviation of residuals. "Upper" refers to the number of months for which the deviation exceeds the estimated $(+)$ silver point. "Middle" refers to the number of months for which the deviation is bounded by the estimated $(+)$ and (-) silver point. "Lower" refers to the number of months for which the deviation exceeds in absolute value the estimated (-) silver point. 
The estimates of the thresholds are $0.60 \%$ and $0.33 \%$ respectively, for Jinan and Qingdao, less than that of Tianjin. These estimates seem reasonable as Jinan and Qingdao are on the way from Shanghai to Tianjin, and the estimates favorably match trade costs derived from contemporaneous accounts. That is, while shipping silver between Shanghai and Jinan could be done by railroad at a freight of $0.46 \%(\mathrm{Su}, 1921, \mathrm{p} .40)$, and shipping silver between Shanghai and Qingdao by seaway entailed a freight of $0.30 \%$ (Jin, 1925, p.278), both were substantially less than the trade cost between Shanghai and Tianjin. For both series, we cannot reject the hypothesis of outer-regime convergence toward the thresholds, and no convergence in the middle regime 44

The results from the southeast and southwest cities lead to the conclusion of financial disintegration between Shanghai and such remote areas. First, the estimates of thresholds for these cities varies from $3 \%$ to $4 \%$. This was not only many times those generated from the major hubs in the central area, but also many times the freights of the silver trade derived from contemporaneous accounts. For instance, the freights from Shanghai to Chongqing via the Yangtze River was $0.5 \%$, and from Shanghai to Guangzhou by seaway were only $0.25 \%$ (Su, 1921, p.169, p.176). Though we find no information on the freights of direct-steamer from Wanxian (a smaller city on the upper Yangtze River) to Shanghai, the freights from Wanxian to Hankou via the Yangtze River were estimated to be merely $0.45 \%$ (Su, 1921, p.163, p.188), and adding a cost from Hankou to Shanghai would increase the total cost to around $1 \% 45$ Given both the large exchange rate deviations and large values of silver point estimates, there were clearly other significant frictions preventing trade. These included higher risk of expropriation or robbery given the lower governmental control over such areas, but also informational and institutional barriers to the silver trade 46

Second, for all these remote cities, the outer regimes show barely any convergence, and tend to have roots closer to unity than the middle regimes. For instance, for the Chongqing series, deviations are reduced by 5.9 per cent and 2.9 per cent within one week in the upper and lower regimes (implying half-lives of 12 and 23 weeks), respectively. Moreover, the asymptotic confidence intervals of the thresholds are too wide hence they fall out of our grid search, indicating inaccurate estimates. The modified likelihood ratio test for testing linear versus threshold mod-

\footnotetext{
${ }^{44}$ However, for each series the outer-regimes combined account for more than half the observations, indicating less reliable estimates of silver points, or persistent arbitrage opportunities. We see this as a sign of a lower degree of market integration.

${ }^{45}$ Most of our remote cities in the southern regions were well connected with Shanghai by waterway: Chongqing and Wanxian were connected via the Yangtze River, and Guangzhou by seaway. Therefore, the low level of integration with these cities cannot be explained by freight costs alone. The only exception in our sample is Chengdu, which was not well connected with other cities (including Shanghai) by either any waterway or railway, and accordingly faced high freight costs: $1.9 \%$ from Hankou, plus $0.6 \%$ for Shanghai-Hankou, raising the total for Shanghai-Chengdu to $2.5 \%$ (Su, 1921, p.183).

${ }^{46}$ For example, contemporaneous newspaper reports often warned of the danger to life and property of transporting cargo to the southern regions not under government control. See, for example, the reports on 'Robbers of Szechuan [Sichuan]' (North-China Daily News July 8, 1921, p.10; September 14, 1921, p.9). Additionally, the shape and weight of silver currency circulated in Sichuan or Guangdong were quite distinct from those in Central and North China. The sycee in Sichuan province were generally ingots of a value of 10 taels. Shanghai's sycee was worth 50 taels; the same was true for the Hankou and Tianjin sycee (Kann, 1927, p.66). In Guangzhou, the principal silver currency in use was not the sycee, but the Guangzhou dollar consisting of five 20-cent coins or ten 10-cent coins $(\mathrm{Su}, 1921, \mathrm{p} .195)$. This means that when Shanghai sycee was taken to Sichuan or Guangdong it had to be recast, incurring a higher cost than the assaying cost when taken to Hankou or Tianjin.
} 
els (Cryer and Chan, 2008, p.401) accepts the null hypothesis of linearity for all exchange rate series for the remote cities. In light of this, we also run a linear autoregressive (AR) model for each of these series. The sum of the estimates of the AR coefficient are 0.935, 0.971, 0.948 and 0.939 for the Chongqing, Chengdu, Wanxian and Guangzhou series, respectively. The average half-life for the exchange rate deviations was 14.6 weeks (more than one quarter), implying a slow speed of parity reversion, which suggests weak silver point arbitrage and market integration.

\subsection{Interpretation}

Our results have revealed a complex financial system within China, a country which had both integrated and segmented markets that coexisted. On one hand, the financial integration between China's major economic hubs in the Lower Yangzi Valley and the coastal areas in the north of the country was remarkably high even by the standards of Western economies. On the other hand, the results from remote southwest and southeast areas suggest financial market fragmentation. This result is explained by inadequate transportation infrastructure to the latter regions along with the existence of multiple currencies and monetary standards which imposed high transaction costs ${ }^{47}$

However, despite the fragmentation of silver standards, the market behaved efficiently to ensure that arbitrage opportunities did not persist for long in the major commercial centers located in north-central China. What can explain this surprising level of financial integration? The first plausible driving force behind the development of financial integration was the industrialization, economic restructuring, and financial modernization of the Late Qing and the succeeding Warlord periods. The opening of the economy since the first Opium War, and the modernization reforms from the end of the nineteenth century brought new businesses and technologies such as rail networks and the telegraph which improved commodity and capital flows (Tang, 2016). The length of the railroad network grew from being almost nonexistent in 1900 to 10,000 kilometers by 1911 (Yan, 1955, p.180). In particular, newly constructed north-south lines, the Pinghan rail and the Jinpu rail, were completed in 1906 and 1912. These slashed economic distances dominated by rivers flowing from west to east. Western influence mattered: almost all of China's railways constructed in this period were financed by foreign debt issues underwritten by European-led banking syndicates, which obtained right of way and promises of repayment from the net revenues of the railroad. Chinese railways were constructed, owned, and operated by managers designated by the external financial consortium who financed the loans (Goetzmann et al., 2007).

From the 1870s, Western powers also took the lead in setting up telegraph lines along China's east coast. Together, the completion of railway and telegraph connections linking Beijing and Hankou reduced the time needed to ship goods from 150 to only 3 days (Brandt et al., 2014). The availability of railroads and telegraphs substantially reduced the costs of silver flows $\mathrm{Ma}$ and Zhao, 2020). Transport development in turn supported economic specialization, stimulating

\footnotetext{
${ }^{47}$ The lack of a common monetary standard throughout the country inevitably increased transaction costs. In Manchuria in the late 1920s, for example, multiple monies seem to have been one cause of economic instability (Kaminishi, 2013).
} 
further commercialization in a wide range of industries.

A second driving force which contributed to financial integration was a sweeping transformation which occurred in money and banking. China's Republican era inherited a pre-modern monetary system, but a modern banking system expanded rapidly in the early twentieth century. By the 1930s, the branch network of banks extended to over 500 localities throughout the country (Rawski, 1989, p.136). Both the privileges and autonomy of treaty ports strengthened in the Warlord Ear of weakened central government. In particular, the International Settlements in Shanghai, Tianjin and Hankou sheltered banks and other financial institutions from the predatory attempts of the fiscally strapped government. The freedom of association in the treaty ports fostered an explosive growth of chambers of commerce and associations of bankers, lawyers, and accountants (Brandt et al. 2014). Against this background, a strong autonomous banking community led by the Chinese Bankers' Association and the Native Bankers' Association (established in 1915 and 1917, respectively) rose in Shanghai. They coordinated with the Nanjing government to practice the monetary reform in 1933, abolishing the tael and retaining the dollar as the sole unit of account in China 48

Overall, then, Western institutions and technologies such as the railway, the telegraph and innovations in money and finance had a positive effect on China's market development, even though they represented a threat to Chinese sovereignty (Ma, 2008a; Brandt et al., 2014). However, for a large country, China's railway network was limited, and confined to northern and central China 49 They linked the major cities of Shanghai and Hankou with Beijing and Tianjin, but did not serve other parts of the country, as we show in Figure 1. Cities in Southeast and Southwest China hence faced high transport costs and were also not under central government control. Moreover, China's modern banking network was developed mainly among port cities. This explains the coexistence of both integrated and segmented financial markets 50

\section{Conclusion}

The study of gold point arbitrage and the efficiency of the gold standard has been one of the most actively pursued avenues of research in economic history. However, not much research exists about countries outside the gold club. In the present paper we have focused on the case of interwar China, the world's most populous country and the only major country on a silver standard at the time. We have examined the efficiency of the silver standard and assessed the degree of financial market integration before the Second World War. To do this, we estimated silver points between Shanghai and nine commercial cities throughout the country. Based on a compilation of high-frequency exchange data, we find that for both major commercial hubs

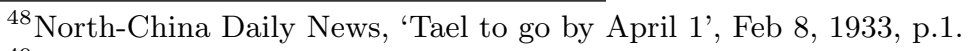

${ }^{49}$ See for example, the comparison with the much more extensive rail network of Japan (Koyama et al., 2018).

${ }^{50}$ We attribute our findings of integration among many cities also to the lower labor costs in China. Real wages were considerably lower in China that they were in Europe and the United States, and nominal wages even more so (Allen et al. 2011). This gave China an advantage in the labor costs component of transportation costs. Assay fees and coolie hire mainly involved labor costs, and freights, wharfage/dock dues as well as packaging in wooden boxes also had a labor cost component. Transportation mostly involved labor costs, with the exception of freight, interest, and insurance premia.
} 
and smaller cities in north and central China, financial markets behaved efficiently despite the fragmentation of silver standards. Our inferred measures of silver points are low and favorably match the measured costs of silver shipments derived from contemporaneous accounts. The daily observations of silver-point violations were rare, silver-point violations did not persist for long, and silver currency shipments generally occurred in the profitable direction as a response to silver-point violations. Our period witnessed surprising effectiveness of silver arbitrageurs in preventing and removing silver-point violations, although this process did not remain unaffected by civil strife. For this region of China the exchange-market efficiency of its silver standard was not much different in magnitude to that of the classical Dollar-Sterling gold standard, though we find considerably lower levels of integration for more remote cities. Overall, however, we find a fairly high level of financial market integration in Republican China, though with substantial regional variation. It is remarkable that this occurred in the era of political decentralization and political turmoil known as the Warlord Era. We emphasize several factors which explain our findings: the growing railway and telegraph network, innovations in money and banking, and low labor costs. As a result of these forces, political fragmentation and low state capacity only led to segmented markets and high transaction costs in parts of China. The fact that monetary markets were becoming integrated must have been one factor promoting economic growth in the regions around Shanghai at this time.

Market performance in remote regions was lower than in the north-central economic hubs, however: a high level of market integration applied only in the latter region. Our econometric analysis shows that both independent and integrated markets coexisted. Finally, it should be emphasized that our findings are based on evidence from financial markets. Hence, they do not necessarily apply to integration of other commodity markets. This is especially true since as a commodity used for currency, silver has a high value-to-weight ratio. Goods with lower value-to-weight ratios, such as grain, are less profitable to arbitrage under normal circumstances and those markets are therefore certain to have been less integrated.

\section{Published Primary Sources}

Banker Weekly. (Yinhang zhoubao). Compiled by the Shanghai Bankers' Association, Shanghai, 1920-1933.

China Press 1924. Kiangsu-Chekiang War Will React On Shipping. Shanghai, Sepember 5.

China Press 1927. Embargo of Nationalist Government said to be illegal. Shanghai, July 23.

Chinese Weekly Economic Bulletin. (Zhongwai Jingji Zhoukan). Compiled by the Chinese Government Bureau of Economic Information, Beijing, 1924.

Chung Hwa English Weekly. Shanghai. 1924.

Economic Statistics. (Jingji tongji). Compiled by the Banker Weekly office, Shanghai, 1923-1933.

Hankou Bankers' Magazine. (Yinhang zazhi). Compiled by the Hankao Bankers' Association, Hankou, 1923-1927. 
North-China Daily News. (Zilin xibao). Compiled by the Zilin xibao office, Shanghai, 1920-1933.

North-China Herald. The Bank of China Report. April 3. 1935.

Peking Bankers' Magazine. (Yinhang yuekan). Compiled by the Beijing Bankers' Association, Beijing, 1921-1928.

Shenbao Newspaper. (Shenbao). Compiled by the Shenbao office, Shanghai, 1920-1933.

Shibao Newspaper. (Eastern Times). Compiled by the Shibao office, Shanghai, 1921-1931.

Zhonghua Gongchengshi Xuehui Huibao (Journal of the Chinese Institute of Engineers), 1917 vol. 4 (12), p.1. Zhongguo jingnei tielu quantu (Railway map in China).

\section{SECONDARY SOURCES}

Allen, R. C., Bassino, J.-P., Ma, D., Moll-Murata, C., and Van Zanden, J. L. Wages, prices, and living standards in China, 1738-1925: in comparison with Europe, Japan, and India. The Economic History Review, 64:8-38, 2011.

Bernhofen, D. M., Eberhardt, M., Li, J., and Morgan, S. Assessing market (dis) integration in early modern China and Europe. Working Paper 5580, CESifo, 2015.

Billingsley, P. Bandits in Republican China. Stanford University Press, 1988.

Brandt, L. Commercialization and Agricultural Development: Central and Eastern China, 18701937. Cambridge University Press, 1989.

Brandt, L., Ma, D., and Rawski, T. G. From divergence to convergence: Reevaluating the history behind China's economic boom. Journal of Economic Literature, 52(1):45-123, 2014.

Bureau of International Trade, Ministry of Industry. (Shiyebu guoji maoyiju). Zhongguo shiye zhi: Jiangsusheng (Records of China's industries: Jiangsu province) Shanghai, 1932.

Canjels, E., Prakash-Canjels, G., and Taylor, A. M. Measuring market integration: Foreign exchange arbitrage and the gold standard, 1879-1913. The Review of Economics and Statistics, 86(4):868-882, 2004.

Chiao, C. and Yin, L. Farm credit and farm ownership. Economic Facts, 4:188-196, 1937.

Clark, T. A. Violations of the gold points, 1890-1908. Journal of Political Economy, 92(5): 791-823, 1984.

Coleman, A. The pitfalls of estimating transactions costs from price data: Evidence from transatlantic gold-point arbitrage, 1886-1905. Explorations in Economic History, 44(3):387-410, 2007.

Cryer, J. D. and Chan, K.-S. Time Series Analysis with Applications in R. Springer, 2008. 
Du, X. Jindai zhongguo huobi shichangde zhenghe yu fenge [the integration and disintegration of the currency market in modern china]. Zhongguo shehui jingjishi yanjiu (Journal of Chinese Social and Economic History), 3:85-100, 2018.

Elvin, M. The Retreat of the Elephants: An Environmental History of China. Yale University Press, 2004.

Esteves, R. P., Reis, J., and Ferramosca, F. Market integration in the golden periphery: The Lisbon/London exchange, 1854-1891. Explorations in Economic History, 46(3):324-345, 2009.

Feng, Y. Yangli yu yinchai zhiyiyi (the meaning of silver dollar exchange rate and lending rate). Yinhang Zhoubao (Banker's Weekly), 10(29):41-45, 1926.

Fernholz, R. T., Mitchener, K. J., and Weidenmier, M. D. Pulling up the tarnished anchor: The end of silver as a global unit of account. Journal of International Money and Finance, 74: 209-228, 2017.

Flandreau, M. The Glitter of Gold: France, Bimetallism, and the Emergence of the International Gold Standard, 1848-1873. Oxford University Press, 2004.

Friedman, M. Franklin D. Roosevelt, silver, and China. Journal of Political Economy, 100(1): 62-83, 1992.

$\mathrm{Fu}, \mathrm{C}$. Gesheng guancheng yu jing gongfacheng zhi bijiao [the comparison of the beijing tael and other provincial taels]. Shiye Zazhi [Industrial Journal], 67:126-127, 1923.

Goetzmann, W. N., Ukhov, A. D., and Zhu, N. China and the world financial markets 18701939: Modern lessons from historical globalization. The Economic History Review, 60(2): 267-312, 2007.

Goodhart, C. E. A. The New York Money Market and the Finance of Trade, 1900-1913. Harvard University Press, 1969.

Hansen, B. E. Inference in TAR models. Studies in Nonlinear Dynamics and Econometrics, 2 (1):1-14, 1997.

Ho, T.-k. and Lai, C.-c. Silver fetters? The rise and fall of the Chinese price level 1928-34. Explorations in Economic History, 50(3):446-462, 2013.

Hoag, C. The Atlantic telegraph cable and capital market information flows. Journal of Economic History, 66(2):342-353, 2006.

Jacks, D., Yan, S., and Zhao, L. Silver points, silver flows, and the measure of Chinese financial integration. Journal of International Economics, 108:377-386, 2017.

Jin, B. Guonei shangye huidui yaolan [domestic commercial exchanges handbook]. Technical report, Shanghai Commercial and Savings Bank, 1925. 
Kaminishi, M. The seasonal demand for multiple monies in Manchuria: re-examining Zhang Zuolin's government's economic policy during the 1920s. Financial History Review, 20(3): 335-359, 2013.

Kann, E. The Currencies of China: An Investigation of Silver and Gold Transactions Affecting China with a Section on Copper. Kelly and Walsh Press, 1927.

Kong, M. Nankai Economic Indicators. China Social Sciences Press, 1988.

Koyama, M., Moriguchi, C., and Sng, T. H. Geopolitics and Asia's little divergence: State building in China and Japan after 1850. Journal of Economic Behavior and Organization, 155:178-204, 2018.

Kuroda, A. The collapse of the Chinese imperial monetary system. In Sugihara, K., editor, Japan, China, and the growth of the Asian international economy, 1850-1949, pages 103-127. Oxford University Press, 2005.

Li, L. F. Information asymmetry and the speed of adjustment: debasements in the mid-sixteenth century. The Economic History Review, 68(4):1203-1225, 2015.

Li, L. Integration and disintegration in North China's grain markets, 1738-1911. Journal of Economic History, 60(3):665-699, 2000.

Luukkonen, R., Saikkonen, P., and Teräsvirta, T. Testing linearity against smooth transition autoregressive models. Biometrika, 75(3):491-499, 1988.

Ma, D. Economic growth in the lower yangzi region of china in 1911-1937: A quantitative and historical analysis. Journal of Economic History, 68(2):355-392, 2008a.

Ma, D. The rise of a financial revolution in republican China in 1900-1937: an institutional narrative. Working Papers 235/2016, LSE Economic History, 2016.

Ma, D. and Zhao, L. A silver transformation: Chinese monetary integration in times of political disintegration, 1898-1933. The Economic History Review, 2020.

Ma, J. Traditional finance and China's agricultural trade, 1920-1933. Modern China, 34(3): 344-371, 2008b.

Marcuzzo, M. C. and Rosselli, A. Profitability in the international gold market in the early history of the gold standard. Economica, 66(2):385-406, 1987.

Meissner, C. M. A new world order: Explaining the international diffusion of the gold standard, 1870-1913. Journal of International Economics, 66(2):385-406, 2005.

Mitchener, K. J., Shizume, M., and Weidenmier, M. D. Why did countries adopt the gold standard? Lessons from Japan. Journal of Economic History, 70(1):27-56, 2010.

Morgenstern, O. International Financial Transactions and Business Cycles, volume 8. Princeton University Press, 1959. 
Morota, H. Money supply mechanisms and modernization of the Tianjin financial market from the 1920s to the 1930s. Socio-Economic History, 79:373-394, 2013.

Nishimura, S. The foreign and native banks in China: Chop loans in Shanghai and Hankow before 1914. Modern Asian Studies, 39(1):109-132, 2005.

Nogues-Marco, P. Competing bimetallic ratios: Amsterdam, London, and bullion arbitrage in mid-eighteenth century. Journal of Economic History, 73(2):445-476, 2013.

North-China Daily News. (Zilin xibao). Compiled by the Zilin xibao office, Shanghai, 1920-1933.

Officer, L. H. The remarkable efficiency of the dollar-sterling gold standard, 1890-1906. Journal of Economic History, 49(1):1-41, 1989.

Officer, L. H. Between the Dollar-Sterling Gold Points: Exchange Rates, Parity and Market Behavior. Cambridge University Press, 1996.

People's Bank of China. Financial Markets in Modern China. China Financial Publishing House, 1989.

People's Bank of China (Shanghai Branch). Shanghai qianzhuang shiliao (Historical Materials of Shanghai Native Banks). Shanghai renmin chubanshe, 1960.

Perkins, D. H. Agricultural development in China, 1368-1968. Edinburg University Press, 1969.

Rawski, E. S. Agricultural change and the peasant. Harvard University Press, 1972.

Rawski, T. G. Economic Growth in Prewar China. University of California Press, 1989.

Sheridan, E. J. China in Disintegration: The Republican Era in Chinese History, 1912-1949. New York: The Free Press, 1975.

Shiue, C. Transport costs and the geography of arbitrage in eighteenth-century China. American Economic Review, 92(5):1406-1419, 2002.

Shiue, C. and Keller, W. Markets in China and Europe on the eve of the industrial revolution. American Economic Review, 97(4):1189-1216, 2007.

Skinner, W. G. Cities and the hierarchy of local systems. In Skinner, W. G., editor, The City in Late Imperial China. Stanford University Press, 1977.

Sng, T. H. Size and dynastic decline: the principal-agent problem in late imperial China 17001850. Explorations in Economic History, 54(107-127), 2014.

Spiller, P. T. and Wood, R. Arbitrage during the dollar-sterling gold standard, 1899-1908: An econometric approach. Journal of Political Economy, 96(4):882-892, 1988.

Steinwender, C. Real effects of information frictions: when the States and the Kingdom became united. American Economic Review, 108(3):657-696, 2018. 
Su, C. Neiguo huidui daquan (Book of Domestic Exchanges). Beijing: No.1 Business School, 1921.

Tang, J. Interest Rates and Financial Market Integration: a Long-Run Perpsective on China. PhD thesis, The London School of Economics and Political Science, 2016.

Taylor, A. M. Potential pitfalls for the purchasing-power-parity puzzle? sampling and specification biases in mean-reversion tests of the law of one price. Econometrica, 69(2):473-498, 2001.

Tsay, R. S. Nonlinearity tests for time series. Biometrika, 73(2):1986, 1986.

Wang, Y.-C. Secular trends of rice prices in the Yangtze Delta, 1638-1935. In Rawski, T. G. and Li, L., editors, Chinese History in Economic Perspective, pages 35-68. University of California Press, 1992.

Wu, D. Yige xinde waihui zhishu (A New Exchange Rate Index). Review of Political Economics, $3(3): 463-509,1935$ a.

Wu, L. The crucial role of the Chinese native banks. Far Eastern Survey, 4(12):89-93, 1935b.

Yan, H. Zhongguo de huobi jinrong tixi, 1600-1949: Jiyu jingji yunxing yu jingji jindaihua de yanjiu (Monetary and Financial Systems of Modern China from 1600-1949: A Study on Economic Performance and Modernization). People's University Press, 2012.

Yan, Z. Zhongguo jindai jingjishi tongji ziliao xuanji (Statistical Materials on the Economic History of Modern China). Kexue chubanshe, 1955.

Yang, Y. Zhongguo jinrong lun (Chinese Finance). Liming chubanshe, 1936.

Young, J. The Shanghai tael. American Economic Review, 21(4):682-684, 1931.

Yu, S. Hankou yangliyin zhi xiaomie (The Elimination of the Hankou Tael). Banker's Weekly, 28(3):28-31, 1928. 
Appendix A. Examples of Exchange Rate Data

Figure A.1: Domestic exchange rate across Shanghai and outports tabulated in the Shenbao Newspaper April 20, 1927, p. 12
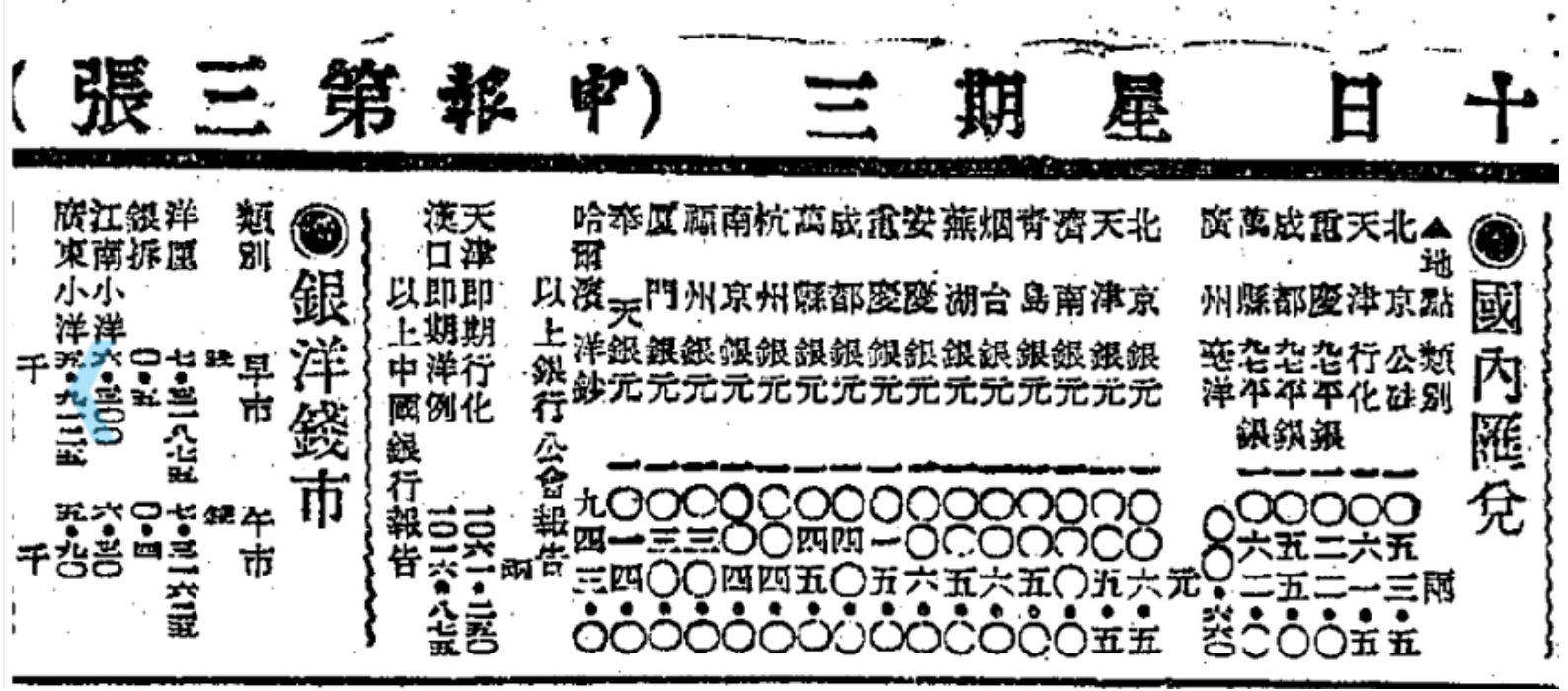

Figure A.2: Silver flow volume across Shanghai and outports tabulated in the North-China Daily News, February 2, 1929, p.3

\section{WEEK'S EXCHANGE NOTES}

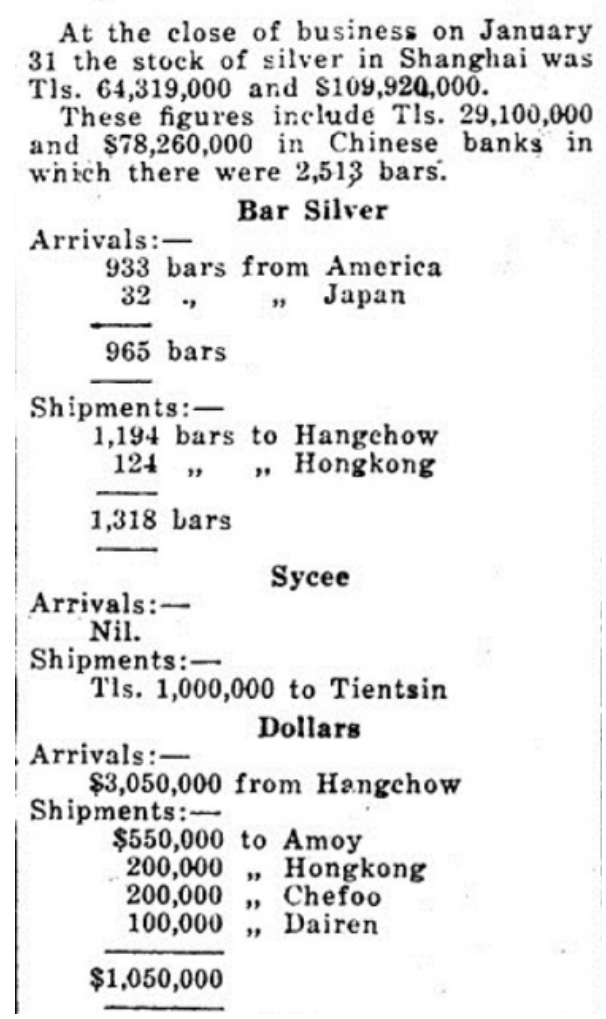




\section{A.1. Robustness: asymmetry in trade costs}

It seems plausible to impose a symmetric threshold $(\theta)$ in the TAR model as in Equation (1), since an arbitrage opportunity would arise if the absolute deviation is larger than trade costs, as shown in the mechanics of silver point arbitrage in Tables 1-2. But it could be that this does not apply perfectly for all our city pairs, so as a robustness exercise, we now allow for the possibility of asymmetry in trade costs. The results of this exercise are reported in Table A1 and suggest that no great damage is done by imposing symmetric thresholds. For Hankou, the estimates of lower and upper silver points are almost symmetric. For Tianjin, the upper silver point estimate is larger when compared to its lower counterpart (in absolute value), but not by much. For Beijing, we only arrived at the lower silver point estimate at 5 percent level of significance, which is close (in absolute value) to the estimated threshold from the asymmetric model. 
Table A1: Summary results of the asymmetric TAR model, daily data

\begin{tabular}{|c|c|c|c|}
\hline & $\begin{array}{l}\text { Tianjin } \\
5 / 1920- \\
5 / 1933\end{array}$ & $\begin{array}{c}\text { Hankou } \\
5 / 1920- \\
3 / 1933\end{array}$ & $\begin{array}{l}\text { Beijing } \\
5 / 1923- \\
12 / 1931\end{array}$ \\
\hline$\theta_{1}$ & 1.02 & 0.726 & 0.837 \\
\hline$\theta_{2}$ & -0.706 & -0.731 & -0.763 \\
\hline$\sum_{i=1}^{k} \beta_{i}^{u}$ & 0.96 & 0.964 & 0.946 \\
\hline$\sum_{i=1}^{k} \beta_{i}^{m}$ & 0.984 & 0.983 & 0.981 \\
\hline$\sum_{i=1}^{k} \beta_{i}^{l}$ & 0.963 & 0.95 & 0.97 \\
\hline $\log \mathrm{L}$ & 1949.91 & 2560.42 & 1465.37 \\
\hline$\sigma$ & 0.141 & 0.114 & 0.135 \\
\hline \multicolumn{4}{|l|}{$\begin{array}{l}\text { Regime } \\
\text { (days) }\end{array}$} \\
\hline $\begin{array}{c}\text { Upper } \\
\theta,+\infty \\
\end{array}$ & 356 & 186 & 179 \\
\hline$\underset{-\theta,+\theta}{\text { Middle }}$ & 3162 & 3052 & 1942 \\
\hline $\begin{array}{l}\text { Lower } \\
-\infty,-\theta\end{array}$ & 167 & 145 & 391 \\
\hline
\end{tabular}

Note: The lagged order ks in the TAR model are chosen to minimize the BIC ( $\mathrm{k}=2$ for the Hankou series and $\mathrm{k}$ $=1$ for the Tianjin and Beijing series). $\log \mathrm{L}$ is the loglikelihood value and is the standard deviation of residuals. "Upper" refers to the number of months for which the deviation exceeds the estimated $(+)$ silver point. "Middle" refers to the number of months for which the deviation is bounded by the estimated $(+)$ and (-) silver point. "Lower" refers to the number of months for which the deviation is exceeds in absolute value the estimated (-) silver point. 